\title{
Interleukin-6 Protects Anterior Horn Neurons from Lethal Virus-Induced Injury
}

\author{
Kevin D. Pavelko, ${ }^{1}$ Charles L. Howe, ${ }^{1}$ Kristen M. Drescher, ${ }^{2}$ Jeff D. Gamez, ${ }^{1}$ Aaron J. Johnson, ${ }^{1}$ Tao Wei, ${ }^{3}$ \\ Richard M. Ransohoff, ${ }^{3}$ and Moses Rodriguez ${ }^{1}$ \\ ${ }^{1}$ Departments of Immunology and Neurology, Mayo Clinic, Rochester, Minnesota 55905, 22Department of Medical Microbiology and Immunology, \\ Creighton University, Omaha, Nebraska 68178, and ${ }^{3}$ Department of Neurosciences, Lerner Research Institute, The Cleveland Clinic Foundation, Cleveland, \\ Ohio 44195
}

We evaluated the role of interleukin-6 (IL-6) in neuronal injury after CNS infection. IL- $6^{-1-}$ and IL- $6^{+/+}$mice of resistant major

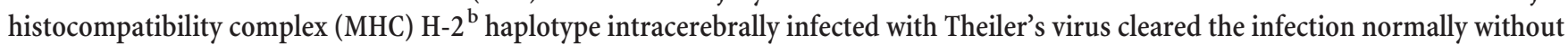
development of viral persistence, lethal neuronal infection, or late phase demyelination. In contrast, infection of IL-6 ${ }^{-/-}$mice on a susceptible $\mathrm{H}-2^{\mathrm{q}}$ haplotype resulted in frequent deaths and severe neurologic deficits within 2 weeks of infection as compared with infected IL- ${ }^{+/+}$H-2 ${ }^{q}$ littermate controls. Morphologic analysis demonstrated dramatic injury to anterior horn neurons of IL- $6^{-1-}$ $\mathrm{H}-2^{\mathrm{q}}$ mice at $12 \mathrm{~d}$ after infection. Infectious viral titers in the CNS (brain and spinal cord combined) were equivalent between IL- $6^{-1-}$ H- $2^{\mathrm{q}}$ and IL- $6^{+/+}$H-2 ${ }^{\mathrm{q}}$ mice. In contrast, more viral RNA was detected in the spinal cord of IL- $6^{-1-}$ mice compared with IL- $6^{+/+}$H- $2^{\mathrm{q}}$ mice. Virus antigen was localized predominantly to anterior horn cells in infected IL- $6^{-1-} \mathrm{H}-2^{\mathrm{q}}$ mice. IL- 6 deletion did not affect the humoral response directed against virus, nor did it affect the expression of CD4, CD8, MHC class I, or MHC class II in the CNS. Importantly, IL- 6 was expressed by astrocytes of infected IL- $6^{+/+}$mice but not in astrocytes of IL- $6^{-1-}$ mice or uninfected IL- $6^{+/+}$mice. Furthermore, expression of various chemokines was robust at $12 \mathrm{~d}$ after infection in both H-2 ${ }^{\mathrm{b}}$ and H-2 ${ }^{\mathrm{q}} \mathrm{IL}-6^{-1-}$ mice, indicating that intrinsic CNS inflammatory responses did not depend on the presence of IL-6. Finally, in vitro analysis of virus-induced death in neuroblastoma-spinal cord-34 motor neurons and primary anterior horn cell neurons showed that IL-6 exerted a neuroprotective effect. These data support the hypothesis that IL-6 plays a critical role in protecting specific populations of neurons from irreversible injury.

Key words: Theiler's murine encephalomyelitis virus; interleukin-6; neuron; chemokine; CNS; multiple sclerosis

\section{Introduction}

A major area of investigation in neurobiology is directed at understanding factors that participate in neuronal survival versus death. A number of neurotrophic growth factors have been identified that promote either neuronal survival or differentiation (Carlson et al., 1999; Middleton et al., 2000; Strelau et al., 2000). Less attention has been given to the role of cytokines, because these soluble factors are primarily thought of as immune modulators. We chose to study the role of interleukin-6 (IL-6) in neuronal survival because its signal transducing protein, gp130, is also used by well characterized neurotrophic factors such as ciliary neurotrophic factor (Kopf et al., 1994). IL-6 binds to a specific receptor that subsequently induces homodimerization of gp130, ultimately leading to activation of the Janus kinase/signal transducer and activator of transcription (STAT) signaling pathway. This results in tyrosine phosphorylation of acute phase response factor/STAT3 and its translocation to the nucleus (Akira, 1997). This signaling cascade is shared by several IL-6-related cytokines, including CNTF, leukemia inhibitory factor, oncostatin-M, and IL-11.

Received May 24, 2002; revised Sept. 26, 2002; accepted 0ct. 25, 2002.

This work was supported by National Institutes of Health Grants P01 NS 38468 (M.R.), R01 NS 32129 (M.R.), and 2 R01 NS 32151 (R.M.R.). We gratefully acknowledge the gift of a LightCycler from the Cleveland area Multiple Sclerosis Women's Committee.

Correspondence should be addressed to Dr. Moses Rodriguez, Departments of Immunology and Neurology, Mayo Clinic, 200 First Street SW, Rochester, MN 55905. E-mail: rodriguez.moses@mayo.edu.

Copyright $\odot 2003$ Society for Neuroscience $\quad 0270-6474 / 03 / 230481-12 \$ 15.00 / 0$
We examined the role of IL-6 in a viral model of CNS infection that localizes predominantly to neurons early in the course of disease. Intracerebral injection of Theiler's murine encephalomyelitis virus (TMEV), a picornavirus, induces a characteristic disease course in the CNS of mice. During the first week of infection, the virus replicates primarily in neurons of the hippocampus, striatum, cortex, and anterior horn of the spinal cord and then is rapidly cleared from the CNS. In addition, distinct arms of the immune system play a critical role in protecting these cell populations from viral-induced pathology (Drescher et al., 1999). Oligodendrocytes and macrophages are also infected early (Njenga et al., 1997), and in animals of susceptible haplotypes, the virus persists in these cells, particularly in the spinal cord white matter and brain stem. To examine the role of IL-6 in TMEV-induced neuropathogenesis, we used mice with a specific disruption in the IL-6 gene. The original IL- $6^{-1-}$ mice were generated on a B6/129 background [major histocompatibility complex (MHC) haplotype $\mathrm{H}-2^{\mathrm{b}}$ ] that is resistant to TMEV persistence and subsequent demyelination. We also generated a line of mice with the MHC haplotype $\mathrm{H}-2^{\mathrm{q}}$ to address the contribution of IL- 6 in mice that develop viral persistence. These mice exhibited decreased survival and increased brain and spinal cord pathology as compared with infected littermate controls. In addition, we found that IL- 6 is critical for the prevention of lethal infection of anterior horn motor neurons in vivo and is able to protect neuroblastoma-spinal cord (NSC)-34 motor 
neurons and primary spinal motor neurons from virusinduced cell death in vitro. Together, these data support the hypothesis that IL-6 is necessary for prevention of neuron injury after virus infection of the CNS.

\section{Materials and Methods}

Virus. The Daniel's strain of TMEV was used for all experiments (Lipton, 1975).

Mice. B6;129S-IL-6 ${ }^{\text {tm1 Kopf }}$ mice were obtained from Jackson Laboratories (Bar Harbor, ME). These mice have a targeted disruption of the IL- 6 gene on chromosome 5 and are homozygous for MHC class-I H- $2^{\text {b }}$. IL- $6^{-1-} \mathrm{H}-2^{\mathrm{q}}$ mice were generated by backcrossing the IL- 6 knock-outs to B10.Q-H2 $\% / \mathrm{SgJ}$ mice (Jackson Laboratories). $\mathrm{F}_{1}$ mice were mated to obtain $\mathrm{F}_{2}$ breeding pairs negative for the wild-type IL- 6 gene and $\mathrm{H}-2^{\mathrm{b}}$. Mice were screened by two different PCR assays. One reaction was performed to detect either the neo cassette used to disrupt the IL- 6 gene or the wild-type gene, and the other was performed to specifically detect the neo cassette (Kopf et al., 1994). The first reaction used primers that flanked the neo cassette on both the forward (5'-TTCCATCCAGTTGCCTTCTTGG-3') and downstream (5'-TTCTCATTTCCACGATTTCCCAG- $3^{\prime}$ ) ends. This reaction resulted in either a 174 bp product for the wild-type allele or a $1314 \mathrm{bp}$ product that included the neo cassette. Mice that were positive for both alleles indicated heterozygosity and were discarded. Preliminary IL- $6^{+/+}$and IL- $6^{-1-}$ mice were further screened for detection of the neo cassette by using an internal $3^{\prime}$ primer (5'-CCGGAGAACCTGCGTGCAATCC-3') with the former 5' primer. This reaction resulted in either a positive $380 \mathrm{bp}$ fragment, indicating the null allele, or in no product, indicating the absence of the neo cassette. Those animals that were IL- $6^{-1-}$ and IL- $6^{+1+}$ were further screened by FACS using an antibody to $\mathrm{H}-2^{\mathrm{b}}$ (BD PharMingen, San Diego, CA). Mice that were negative for $\mathrm{H}-2^{\mathrm{b}}$ were used as breeders to establish the $\mathrm{H}-2^{\mathrm{q}}$ line of mice. All offspring were screened by both assays to confirm genotype. All experiments were controlled by comparing IL- $6^{-/-} \mathrm{H}-2^{\mathrm{q}}$ mice with littermate IL- $6^{+/+} \mathrm{H}-2^{\mathrm{q}}$ mice.

Infection and harvesting of the CNS for morphology. At 4-6 weeks of age, mice were intracerebrally infected with $2 \times 10^{5}$ plaque-forming units (pfu) of TMEV in a total volume of $10 \mu \mathrm{l}$. At various times after infection (or when moribund), mice were perfused via intracardiac puncture with $50 \mathrm{ml}$ of Trump's fixative. Spinal cords and brains were removed and postfixed for $24-48 \mathrm{hr}$ in Trump's fixative in preparation for morphologic analysis.

Spinal cord morphometry. Spinal cords were removed from spinal columns and cut into $1 \mathrm{~mm}$ coronal blocks; every third block was osmicated and embedded in glycol methacrylate (Rodriguez et al., 1986a, 1991a,b). Sections $(2 \mu \mathrm{m})$ were prepared and stained with a modified erichrome/ cresyl violet stain (Pierce and Rodriguez, 1989). Morphological analysis was performed on $12-15$ sections per mouse as described previously (Rodriguez et al., 1986a, 1991a,b). Briefly, each quadrant from every coronal section from each mouse was graded for the presence or absence of gray matter disease, meningeal inflammation, and demyelination. The score was expressed as the percentage of spinal cord quadrants examined with the pathologic abnormality. A maximum score of 100 indicated that there was a particular pathologic abnormality in every quadrant of all spinal cord sections of a given mouse. All grading was performed without knowledge of the experimental group. Additional spinal cord blocks were embedded in paraffin for immunocytochemistry.

Brain pathology. Brain pathology was assessed at day 12 post-infection (p.i.) using our previously described technique (Drescher et al., 1999). After perfusion with Trump's fixative, two coronal cuts were made in the intact brain at the time of removal from the skull (one section through the optic chiasm and a second section through the infundibulum). As a guide we used the atlas of the mouse brain and spinal cord corresponding to sections 220 and 350 (Sidman et al., 1971). This resulted in three blocks that were then embedded in paraffin. This allowed for systematic analysis of the pathology of the cortex, corpus callosum, hippocampus, brainstem, striatum, and cerebellum. The resulting slides were then stained with hematoxylin and eosin. Pathologic scores were assigned without knowledge of experimental group to the following areas of the brain: cortex, corpus callosum, hippocampus, brainstem, striatum, and cerebellum. Each area of the brain was graded on a four-point scale as follows: $0=$ no pathology; $1=$ no tissue destruction but only minimal inflammation; 2 = early tissue destruction (loss of architecture) and moderate inflammation; 3 = definite tissue destruction (demyelination, parenchymal damage, cell death, neurophagia, neuronal vacuolation); $4=$ necrosis (complete loss of all tissue elements with associated cellular debris). Meningeal inflammation was assessed and graded as follows: $0=$ no inflammation; 1 = one cell layer of inflammation; 2 = two cell layers of inflammation; 3 = three cell layers of inflammation; $4=$ four or more cell layers of inflammation. The area with maximal extent of tissue damage was used for assessment of each brain region.

Clinical disease assessment. Mice were assessed clinically by three criteria: appearance, activity, and paralysis. A score for each criterion was given ranging from 0 (no disease) to 3 (severe disease). For appearance, 1 indicated minimal change in coat, 2 indicated a moderate change (scruffy appearance), and 3 indicated a severe change (incontinence and stained coat). For activity, 1 indicated decreased spontaneous movements (minimal ataxia), 2 indicated moderate slowing (minimal spontaneous movements), and 3 indicated severe slowing (no spontaneous movement). For paralysis, 0.5 indicated a spastic extremity, 1 indicated a paralyzed extremity, 1.5 indicated two or more spastic extremities, 2 indicated two paralyzed extremities (unable to walk), 2.5 indicated no righting response, and 3 indicated three or four paralyzed extremities (moribund). The total score for each mouse was the cumulative total from each criterion (maximum of 9).

Survival analysis. Mice were monitored throughout the time of infection, and deaths were recorded at the end of each week.

Virus-specific antibody isotype ELISA. Whole blood was collected from mice at time they were killed, and sera was isolated and stored at $-80^{\circ} \mathrm{C}$. Total serum IgGs and IgMs against TMEV were assessed by ELISA as described previously (Njenga et al., 1996). Virus was adsorbed to 96-well plates (Immulon II; Dynatech Laboratories, Chantilly, VA) and then blocked with $1 \%$ bovine serum albumin (BSA) (Sigma St. Louis, MO) in PBS. Serial serum dilutions were made in $0.2 \%$ BSA/PBS and added in triplicate. Biotinylated anti-mouse IgG or IgM secondary antibodies were used for detection (Jackson ImmunoResearch Labs, Westbury, NY). Signals were amplified with streptavidin-labeled alkalinephosphatase (Jackson ImmunoResearch Labs) and detected using p-nitrophenyl phosphate as the substrate. Absorbances were read at 405 $\mathrm{nm}$ and plotted against serum dilution factors.

Virus neutralization assay. Virus-neutralizing antibodies were assessed as described previously (Rodriguez et al., 2000). Briefly, TMEV was diluted to contain 100 pfu per sample and then mixed with an equal volume of serial twofold dilutions of heat-inactivated sera from infected mice. After incubation on ice for $30 \mathrm{~min}$, this mixture was assayed for infectivity by plaque assay on L2 cells. Data were expressed as the titer that neutralized $90 \%$ of the virus.

Virus plaque assay. Virus titers in brain and spinal cords were performed at various days after TMEV infection. Assays were performed as described (Rodriguez et al., 1986a). Briefly, brain and spinal cords were homogenized to yield a 10\% w/v homogenate in DMEM (BioWhittaker, Walkersville, MD). Samples were sonicated, clarified by centrifugation, and stored at $-70^{\circ} \mathrm{C}$ until the time of plaque assay. The assay was performed on L2 cells without knowledge of mouse strain. All dilutions were done in triplicate. Data are presented as plaque-forming units per gram of CNS tissue.

Immunostaining for virus antigen. Immunocytochemistry was performed on paraffin-embedded sections as described previously (Drescher et al., 1998). Slides were deparaffinized in xylene and rehydrated through an ethanol series (absolute, 95, 70, 50\%). Virus antigen staining was performed using polyclonal antisera to TMEV (Rodriguez et al., 1993), which reacts strongly with the capsid proteins of TMEV. After incubation with a secondary biotinylated antibody (Vector Laboratories, Burlingame, CA), immunoreactivity was detected using the avidin-biotin immunoperoxidase technique (Vector Laboratories). The reaction was developed using Hanker-Yates reagent with hydrogen peroxide as the substrate (Polysciences, Warrington, PA). Slides were lightly counterstained with Mayer's hematoxylin. The number of virus antigen- 


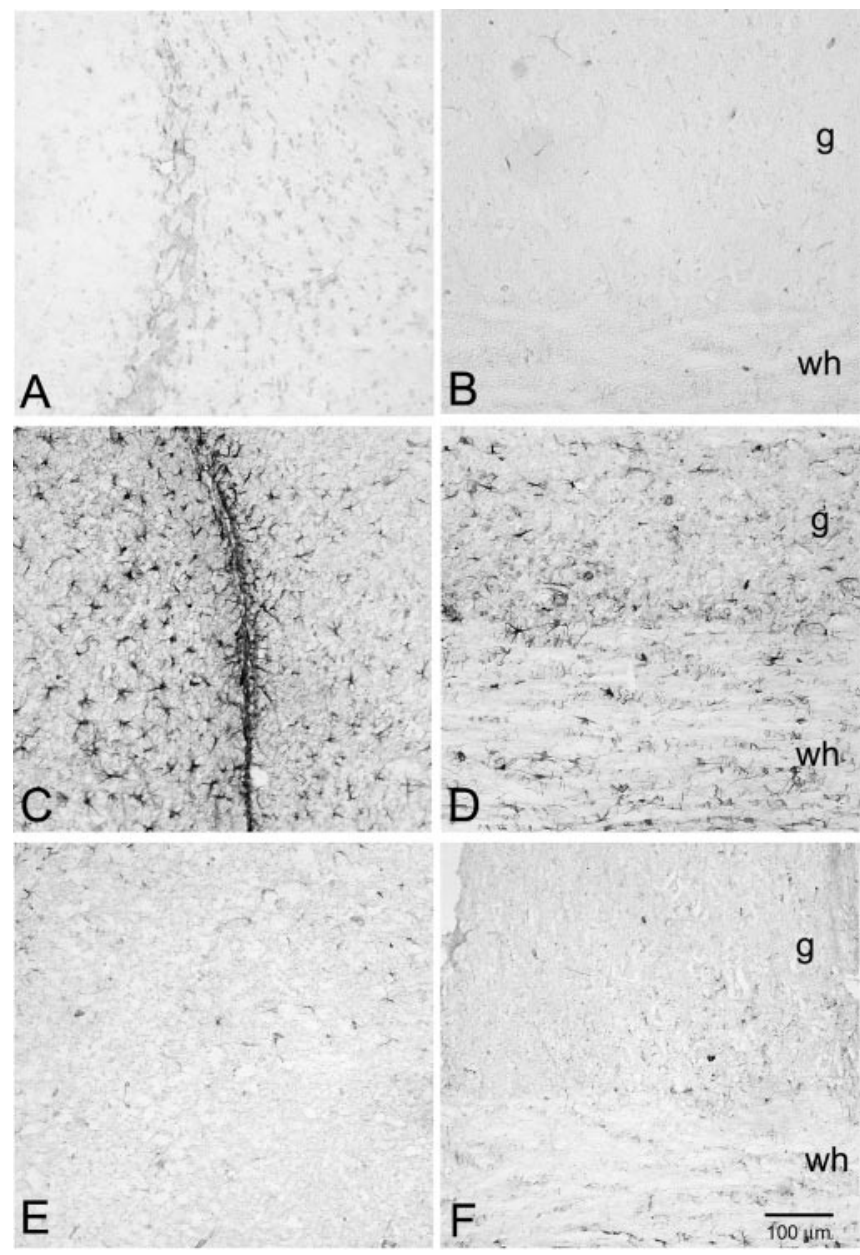

Figure 1. Immunoperoxidase staining for IL-6 antigen using an antibody specific for IL-6. There was no staining for IL-6 in the brain $(A)$ or spinal cord $(B)$ of noninfected mice. C, Prominent staining for IL-6 primarily in astrocytes from the brain of an infected IL- $6^{+/+}$mouse. $D$, Scattered positive staining for IL- 6 in the spinal cord of an infected IL- $6^{+/+}$mouse. Staining is present in both the gray $(g)$ and white $(w h)$ matter. By morphology these cells appear to be either astrocytes or microglia. $E, \mathrm{IL}-6^{-1-} \mathrm{H}-2^{\mathrm{b}}$ mouse shows only minimal background staining in the brain. F, Absence of IL-6 expression in the spinal cord of an infected IL- $6^{-1-}$ mouse.

positive cells was expressed per area of gray matter or white matter in the spinal cord.

Northern hybridization. Brains and cords were removed from $12 \mathrm{~d}$ infected mice, and RNA was isolated using RNA-Stat. Ten micrograms of total RNA were applied to a formaldehyde gel and blotted onto nitrocellulose. Blots were probed with random primer-generated ${ }^{32} \mathrm{P}$-labeled cDNA probe specific for either glyceraldehyde-3' - phosphate dehydrogenase (GAPDH) (a housekeeping gene) or VP2, one of the TMEV capsid proteins. A Storm Phosphorimager was used to measure the amount of radiolabeled probe bound to the specific RNAs.

Immunostaining for CD4, CD8, MHC class I, MHC class II, and IL-6. Frozen sections were prepared by embedding brain and spinal cord tissue from IL- $6^{-1-}$ and IL- $6^{+/+}$in OCT embedding compound. The brain was cut into three coronal blocks, and the spinal cord was removed in three longitudinal sections. The blocks were then frozen and stored in liquid nitrogen until immunostaining for CD4, CD8, MHC class I, MHC class II, and IL-6 was performed. Frozen sections $(10 \mu \mathrm{m})$ of the spinal cord and brain were cut and placed on Superfrost plus slides (Fisher Scientific, Houston, TX) and allowed to air dry. Slides were fixed in 95\% ethanol at $-20^{\circ} \mathrm{C}$ for $20 \mathrm{~min}$ and then washed twice with PBS for $5 \mathrm{~min}$ each. Sections were then blocked with avidin and biotin (Vector) for 10 min each and then washed with PBS. Primary antibodies for CD4, CD8, IL-6 (PharMingen), and antibodies to MHC class I (Y3) and MHC class

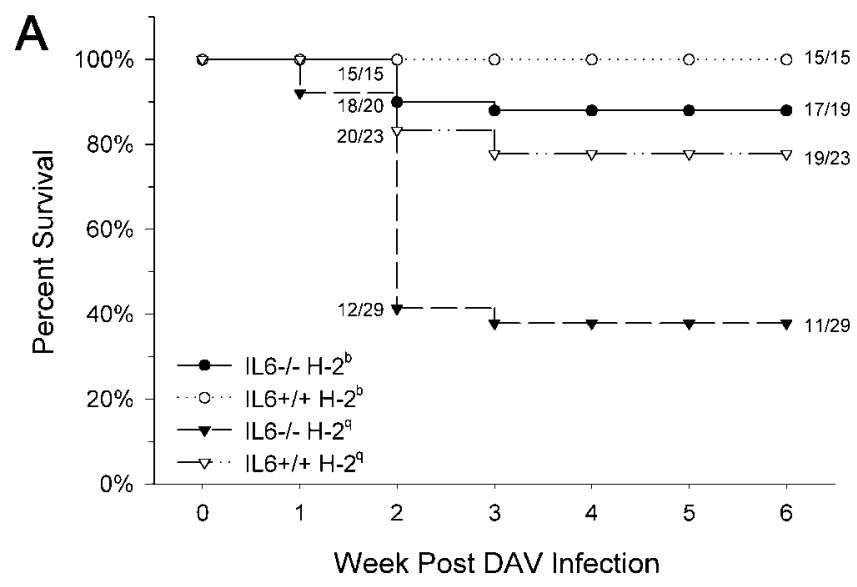

B

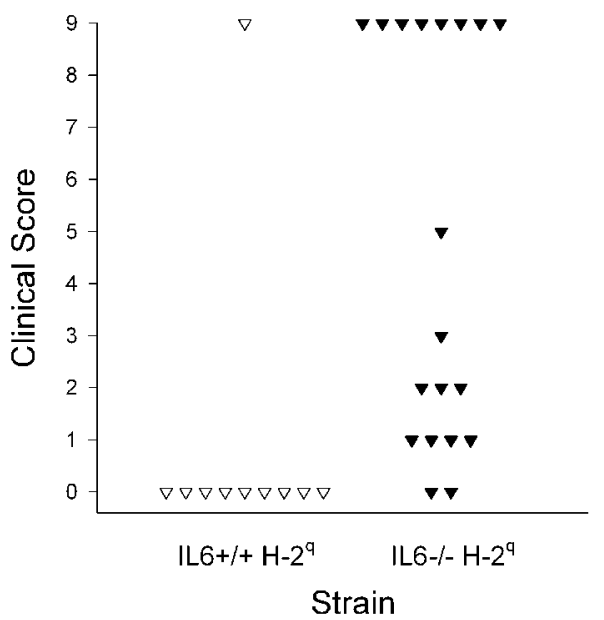

Figure 2. A, Survival analysis of IL- $6^{-1-} \mathrm{H}-2^{\mathrm{b}}, \mathrm{IL}-6^{+/+} \mathrm{H}-2^{\mathrm{b}}, \mathrm{IL}-6^{-1-} \mathrm{H}-2^{\mathrm{q}}$, and IL$6^{+1+} \mathrm{H}-2^{9}$ mice infected intracranially with Theiler's virus. There was a statistically significant decrease in survival in IL-6-deficient mice of susceptible MHC haplotype $\mathrm{H}-2^{\mathrm{q}}$ as compared with $\mathrm{H}-2^{9}$ mice with normal expression of IL- 6 ( $p<0.05$ by $z$ test). In contrast, mice of normally resistant MHC haplotype $\left(H-2^{b}\right)$ showed no significant decrease in survival regardless of IL-6 expression. B, Clinical scores of IL- $6^{+/+} \mathrm{H}-2^{9}$ mice and IL- $6^{-1-} \mathrm{H}-2^{9}$ mice after Theiler's virus infection. Scores were obtained on day 12 after infection. Sixteen of $18 \mathrm{IL}-6^{-1-} \mathrm{H}-2^{\mathrm{q}}$ mice showed neurologic deficits or were moribund. In contrast, 9 of $10 \mathrm{IL}-6^{+/+} \mathrm{H}-2^{9}$ mice were clinically normal. This difference in clinical scores between IL-6 ${ }^{-1-} \mathrm{H}-2^{9}$ and IL- $6^{+/+}$ $\mathrm{H}-2^{\mathrm{q}}$ mice was statistically significant by rank sum $(p<0.001)$. Both IL- $6^{-1-} \mathrm{H}-2^{\mathrm{b}}$ and $\mathrm{IL}-6^{+/+} \mathrm{H}-2^{\mathrm{b}}$ mice remained clinically normal for the $45 \mathrm{~d}$ of observation after virus infection.

II (10216) were used to identify antigens. Detection of primary antibodies was performed by using the appropriate biotin-labeled secondary antibody, and detection was performed using avidin-biotin complex methodology (Vector Labs) and Hanker-Yates (Polysciences). After development, slides were lightly counterstained with hematoxylin, dehydrated, and coverslipped.

Flow cytometric analysis. Cells $\left(10^{6}\right)$ isolated from the brains of two IL- $6^{+/+} \mathrm{H}-2^{\mathrm{q}}$ and two IL- $6^{-1-} \mathrm{H}-2^{\mathrm{q}}$ mice were independently stained with anti-CD8 allophycocyanin (APC), anti-CD4 PerCp, and anti-B220 phycoerythrin (PE) on ice for $20 \mathrm{~min}$. In two parallel experiments with the same brain sample, cells were stained with anti-CD8 APC, anti-CD4 PerCp, and either anti-PanNK PE or anti-Mac1 PE. All antibodies are available from PharMingen. Samples were then washed twice with FACS buffer (1\% BSA and $2 \%$ sodium azide), resuspended in cold PBS, and fixed in $1 \%$ paraformaldehyde. Samples were analyzed on a Becton Dickinson FACScan instrument (Mountain View, CA) using Win MDI software (Scripps, La Jolla, CA). To calculate the relative frequency of lymphocyte subsets to one another in a particular brain cell isolate, all cell types were gated, counted, and compared with the CD4+ T-cell com- 
Table 1. Spinal cord pathology in mice infected with TMEV

\begin{tabular}{|c|c|c|c|c|c|c|}
\hline \multirow[b]{2}{*}{ Strain } & \multirow[b]{2}{*}{ MHC } & \multirow[b]{2}{*}{$\begin{array}{l}\text { No. of } \\
\text { mice }\end{array}$} & \multirow[b]{2}{*}{$\begin{array}{l}\text { Days } \\
\text { p.i. }\end{array}$} & \multicolumn{3}{|c|}{$\begin{array}{l}\text { Percentage of quadrants with disease } \\
\text { (Mean } \pm \text { SEM) }\end{array}$} \\
\hline & & & & $\begin{array}{l}\text { Gray matter } \\
\text { inflammation }\end{array}$ & $\begin{array}{l}\text { Meningeal } \\
\text { inflammation }\end{array}$ & Demyelination \\
\hline IL6+/+ & $\mathrm{H}-2^{\mathrm{b}}$ & 5 & 12 & $2.4 \pm 1.8$ & $0.5 \pm 0.5$ & $1.4 \pm 0.6$ \\
\hline IL6-1- & $\mathrm{H}-2^{\mathrm{b}}$ & 3 & 12 & $5.7 \pm 0.9$ & $1.7 \pm 0.8$ & $1.6 \pm 0.8$ \\
\hline IL6+/+ & $H-2^{q}$ & 14 & 12 & $5.3 \pm 1.0^{*}$ & $6.3 \pm 0.8$ & $4.3 \pm 1.4$ \\
\hline IL6-I- & $H-2^{q}$ & 12 & 12 & $13.5 \pm 3.8^{*}$ & $9.7 \pm 3.3$ & $5.3 \pm 1.0$ \\
\hline IL6+/+ & $\mathrm{H}-2^{\mathrm{b}}$ & 8 & 45 & $0.0 \pm 0.0$ & $0.2 \pm 0.2$ & $0.0 \pm 0.0$ \\
\hline IL6-I- & $\mathrm{H}-2^{\mathrm{b}}$ & 6 & 45 & $0.0 \pm 0.0$ & $0.0 \pm 0.0$ & $0.0 \pm 0.0$ \\
\hline $1 \mathrm{~L} 6+1+$ & $H-2^{q}$ & 10 & 45 & $0.5 \pm 0.3$ & $17.7 \pm 3.3$ & $27.4 \pm 4.0$ \\
\hline IL6-I- & $H-2^{q}$ & 10 & 45 & $8.4 \pm 5.1$ & $7.7 \pm 2.4$ & $19.8 \pm 3.8$ \\
\hline
\end{tabular}

For each mouse, 10-15 spinal cord sections were graded for gray matter inflammation, meningeal inflammation, and demyelination. The data are expressed as the percentage of spinal cord quadrants with disease (mean \pm SEM). *Statistically significant by $t$ test $(p<0.05)$.

partment. Using the CD4 + T-cell compartment as the standard enabled us to estimate the relative frequency of each immune cell compartment across three separate experiments performed on a single brain sample.

Expression of chemokines. The brain and spinal cord were removed from animals on various days after TMEV infection. The tissues were frozen in liquid nitrogen, chilled in isopentane, and stored in liquid nitrogen. Two $30 \mu \mathrm{m}$ cryostat sections of each tissue per animal were stored in sterile tubes at $-80^{\circ} \mathrm{C}$. Trizol (Invitrogen, Gaithersburg, MD) was added ( $500 \mu \mathrm{l}$ for spinal cord sections and $700 \mu \mathrm{l}$ for brain sections), and RNA was precipitated with isopropanol, using $1 \mathrm{ml}$ of $20 \mathrm{mg} / \mathrm{ml}$ glycogen (Roche, Indianapolis, IN) as a carrier at $-20^{\circ} \mathrm{C}$ overnight. RNA concentration was determined by spectrophotometry, and $1 \mathrm{mg}$ of RNA was DNase treated (Invitrogen) according to the manufacturer's instruction. First-strand cDNA was synthesized using $1 \mathrm{mg}$ of DNase-treated RNA, oligo-dT primers, and superscript II (Invitrogen), according to the manufacturer's instruction.

Generation of standard curves. The fragments of mouse MCP-1/chemokine ligand (CCL)2 ( $\sim 400 \mathrm{bp})$, IP-10/CXCL10 ( $600 \mathrm{bp})$, and RANTES/CCL5 $(\sim 400 \mathrm{bp})$ transcripts were amplified in RT-PCR reactions using genespecific primers. The primer pair sequences were as follows: MCP-1 forward, $5^{\prime}$-ATCCCAATGAGTAGGCTGGAGAGC-3', backward, 3'-AAGGCATCACAGTCCGAGTCACAC-5'; IP-10, forward, 5'-CAACCCAAGTGCTGCC-3', backward, 3'-GGGAATTCACCATGGCTTGACCA-5'; RANTES, forward, 5' -TTTGCCTACCTCTCC-CTAGAGCTG-3', backward, 3'-ATGCCGATTTTCCCAGGACC- $5^{\prime}$. The PCR products were subcloned into the PCR 2.1 vector (Original TA cloning kit; Invitrogen, Carlsbad, CA) following the TA cloning kit protocol. The plasmid DNA was quantified by spectrophotometry. Five serial 10 -fold dilutions of plasmid DNA (from $2000 \mathrm{fg}$ to $0.2 \mathrm{fg}$ per reaction) were prepared, amplified by PCR, and labeled with SYBR Green (Roche), which yields a bright fluorescence on binding of double-stranded nucleic acids; this fluorescence abruptly diminishes on denaturation of DNA strands during melting-curve analysis. PCR and analysis to generate standard curves were performed in 20 $\mathrm{ml}$ reactions in glass capillaries, using a LightCycler (Roche) and LightCycler 3 software. For each reaction, melting-curve analysis was used to detect the synthesis of nonspecific products.
Negative controls (omitting input cDNA) were also used in each PCR run to confirm the specificity of PCR products. PCR standard curves were linear across serial 10-fold dilutions, and the melting curve analysis indicated synthesis of a single homogeneous product of expected melting temperature.

Standard curves were generated with each set of samples. The reactions were done in $20 \mathrm{ml}$ capillaries containing $2.5 \mathrm{mM} \mathrm{Mg}^{2+}, 0.2 \mathrm{~mm}$ of each forward and backward primer (identical with those used to generate the plasmid DNA template for standard curve), $1 \times$ DNA Master SYBR Green (LightCycler-DNA Master SYBR Green I kit, Roche), and $2 \mathrm{ml}$ cDNA. Reaction conditions for PCR were as follows: denature at $95^{\circ} \mathrm{C}$ for $1 \mathrm{~min}$; 40 cycles of amplification by denaturing at $95^{\circ} \mathrm{C}$ for $15 \mathrm{sec}$, annealing at $60^{\circ} \mathrm{C}$ for $5 \mathrm{sec}$, and extending at $72^{\circ} \mathrm{C}$ for $15 \mathrm{sec}$. The accumulation of products was monitored by SYBR Green fluorescence at the completion of each cycle. Analysis was performed on the LightCycler 3 software, and results are expressed as the crossing point at which accumulation of PCR products became exponential. Using the standard curves, this value was converted to femtograms of target. Reaction conditions for melting curve analyses were denaturation to $95^{\circ} \mathrm{C}$ at $20^{\circ} \mathrm{C} / \mathrm{sec}$ without plateau phase, annealing at $65^{\circ} \mathrm{C}$ for $15 \mathrm{sec}$, denaturation to $95^{\circ} \mathrm{C}$ at $0.1^{\circ} \mathrm{C} / \mathrm{sec}$, with continuous monitoring of SYBR Green fluorescence.

In vitro protection assay. NSC-34 motor neurons (kindly provided by Dr. Neil Cashman, University of Toronto, Toronto, Ontario) were grown in DMEM supplemented with 10\% FCS and 1\% Pen-Strep. After several propagation passages, cells were switched to a differentiation media consisting of DME/F12 (50:50) supplemented with 1\% FCS, $1 \%$ nonessential amino acids, and 1\% Pen-Strep (Cashman et al., 1992; Eggett et al., 2000). After several passages under these conditions, the cells exhibited neurites and were considered to be differentiated to a motor neuron
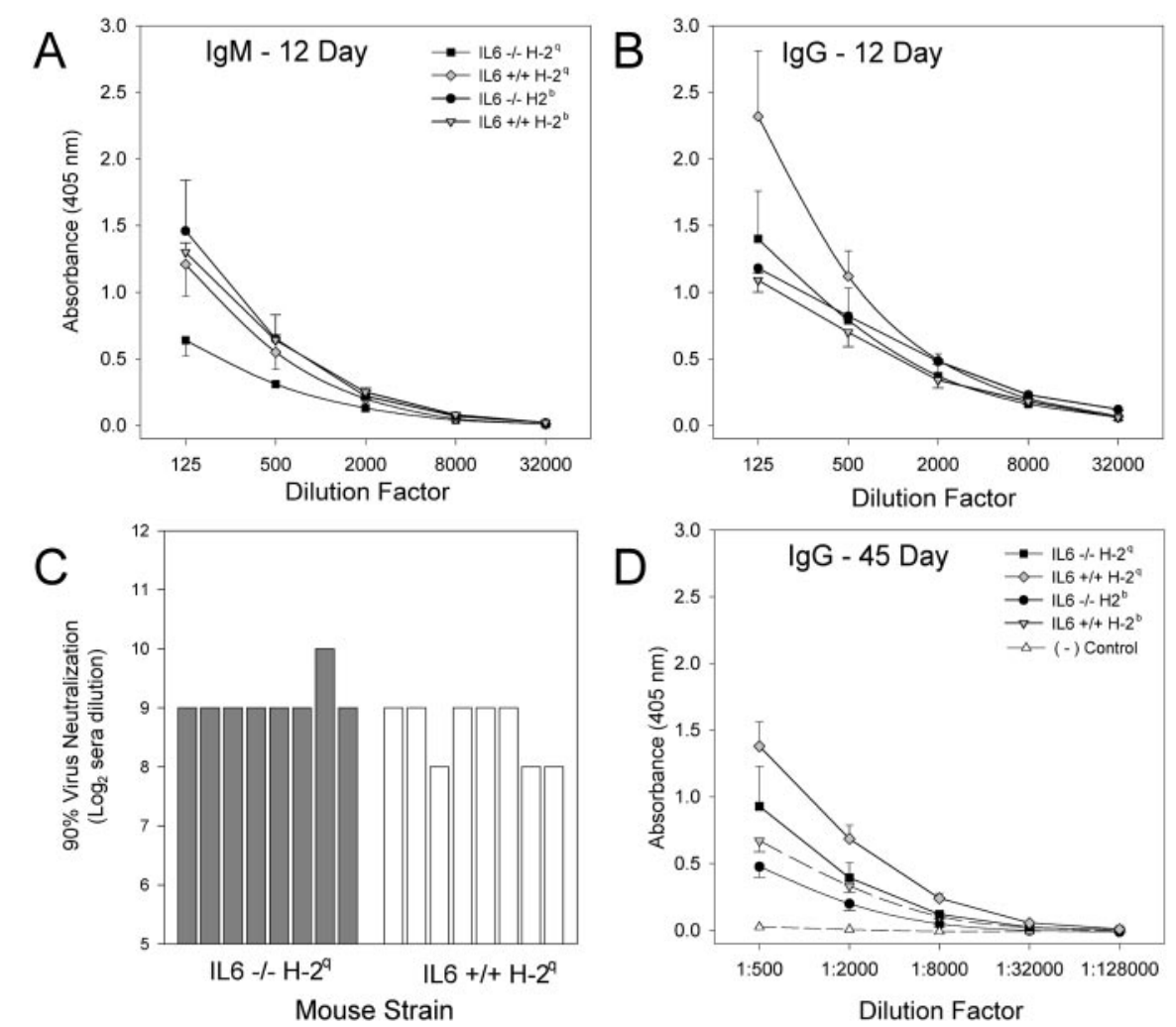

Figure 3. A, ELISA for serum IgM antibodies ( $12 \mathrm{~d}$ after infection) directed against purified TMEV antigens in IL- $6^{-1-} \mathrm{H}-2^{\mathrm{b}}$, $\mathrm{IL}-6^{+1+} \mathrm{H}-2^{\mathrm{b}}, \mathrm{IL}-6^{-1-} \mathrm{H}-2^{\mathrm{q}}$, and IL- $6^{+/+} \mathrm{H}-2^{\mathrm{q}}$ mice. Negative control is from mice not infected with TMEV. Both IL- $6^{-1-}$ and IL- $6^{+/+}$mice developed humoral antibody response to the virus antigen. IL- $6^{-/-} \mathrm{H}-2^{9}$ mice had similar IgM responses at $12 \mathrm{~d}$ as compared with the other experimental groups. B, Virus-specific IgG ELISA at $12 \mathrm{~d}$ after infection also showed no differences between groups. C, Virus neutralization using antiserum from IL- $6^{+/+} \mathrm{H}-2^{\mathrm{q}}$ and IL-6 $6^{-1-} \mathrm{H}-2^{\mathrm{q}}$ mice at $12 \mathrm{~d}$ after infection shows that there was no difference between the groups. Each bar represents one animal. Data are expressed as the $\log _{2}$ dilution of antiserum required to neutralize $90 \%$ of Theiler's virus plaques in L2 cells. D, ELISA for serum lgG at $45 \mathrm{~d}$ after infection. By $45 \mathrm{~d}$, both IL- $6^{-1-}$ and IL- $6^{+/+} \mathrm{H}-2^{q}$ mice had higher responses as compared with IL- $6^{+/+}$or IL- $6^{-1-} \mathrm{H}-2^{\mathrm{b}}$ mice. 


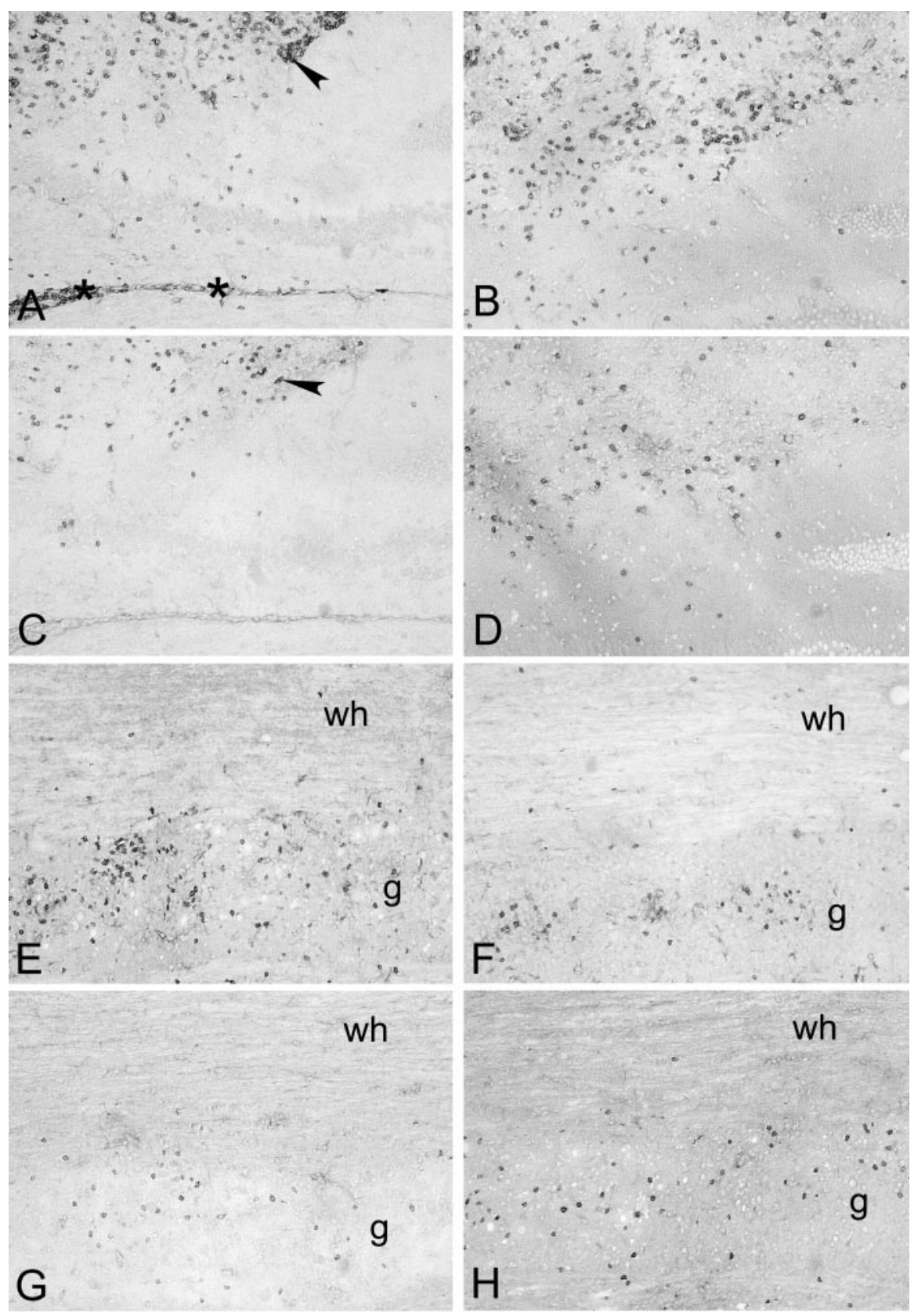

Figure 4. Immunoperoxidase staining for $\mathrm{CD} 4+$ and $\mathrm{CD} 8+\mathrm{T}$ cells in the $\mathrm{CNS}$ of IL- $6^{-1-} \mathrm{H}-2^{9}$ and IL $-6^{+/+} \mathrm{H}-2^{9}$ mice at $12 \mathrm{~d}$ after infection. $A, \mathrm{CD} 4+$ cells are abundant in the brain of IL- $6^{-1-} \mathrm{H}-2^{9}$ mice. Some of the $\mathrm{CD} 4+$ cells are present in the meninges of the brain (asterisk), whereas others are in the parenchyma, frequently in a perivascular location (arrowhead). $B$, $\mathrm{CD} 4+$ cells in the brain of an IL- $6^{+/+}$mouse show a distribution similar to that seen in an IL- $6^{-1-}$ mouse shown in A. C, Serial section from that shown in $A$ (IL-6 $6^{-1-} \mathrm{H}-2^{9}$ mouse) was stained for $\mathrm{CD} 8+\mathrm{T}$ cells. Note that the cells are distributed widely within the brain parenchyma (arrow) and have a distinct distribution compared with CD4+ T cells. D, Serial section from that shown in $B$ (IL-6+/ + mouse) shows that the pattern of CD8 staining is similar to that seen in C (IL- $6^{-1-} \mathrm{H}-2^{q}$ mouse). $E$, CD4-positive cells are present almost exclusively in the gray matter of the spinal cord of an IL-6 ${ }^{-1-} \mathrm{H}-2^{9}$ mouse. Many of the CD4+ cells are clumped together. $F$, Similar distribution of $\mathrm{CD} 4+$ cells in the gray matter of an IL- $6^{+/+}$mouse as compared with E. G, Serial section from that shown in $E$ demonstrates the localization of CD8 $+T$ cells. These cells are more widely scattered in the gray matter as compared with CD4 + T cells. H, Serial section from that shown in F shows similar distribution of CD8 + T cells in the spinal cord of an IL- $6^{+/+}$mouse as compared with an IL- $6^{-1-}$ mouse. $g$, Gray matter; wh, white matter.

phenotype. Such differentiated cells were plated to $70 \%$ confluency on 12 well plates, grown overnight to obtain $>80 \%$ confluency, and then infected with $1.5 \mathrm{pfu}$ of TMEV per cell. At the time of infection, some cells were treated with various concentrations of IL-6 or left untreated. After an overnight incubation, cell survival was measured using a standard MTT assay.

For generation of primary motor neurons, spinal cords were dissected into Hibernate A media supplemented with B27 and then minced with a razor blade and digested in Hibernate A containing papain. After trituration, motor neurons were isolated by centrifugation through an OptiPrep step gradient. Cells were plated on poly-D-lysine and grown in Neurobasal A media containing B27 supplement and b-FGF (10 ng/ml). Morphologically, after 2 weeks in culture, the predominant cell type appeared to be motor neurons, and these cells exhibited large, complex neurite networks. Cultures were analyzed for the effect of IL-6 on survival as described above for NSC-34 cells.

Statistics. Data were analyzed using either the Student's $t$ test for normally distributed data or the Mann-Whitney rank sum test for data that were not normally distributed. Proportional data were evaluated using the $z$ test. The level for significance was set as $p<0.05$ for all tests.

\section{Results}

IL-6 is expressed primarily in astrocytes after Theiler's virus infection

Immunohistochemistry was used to examine the distribution of IL- 6 in the brain and spinal cord. In noninfected IL- $6^{+/+}$ $\mathrm{H}-2^{\mathrm{b}}$ mice there was no expression of IL- 6 in the brain or spinal cord (Fig. $1 A, B$ ). After $7 \mathrm{~d}$ of Theiler's virus infection there was a dramatic upregulation of IL-6 immunoreactivity observed primarily in astrocytes of the brain and spinal cord (Fig. $1 C, D)$. As expected, IL- $6^{-1-} \mathrm{H}-2^{\mathrm{b}}$ mice infected with virus showed no significant IL-6 expression in the brain or spinal cord (Fig. 1E, F).

\section{IL- $6^{-/-}$mice with a normally resistant $\mathrm{H}-2^{\mathrm{b}} \mathrm{MHC}$ remain resistant to persistent TMEV demyelination and neurologic deficits}

Injection of Theiler's virus into the CNS of mice results in two distinct disease phenotypes. Mice of the resistant $\mathrm{H}-2^{\mathrm{b}, \mathrm{k}, \mathrm{d}}$ haplotypes develop acute encephalitis at $7-10$ $\mathrm{d}$ after infection, with virus replication restricted primarily to the hippocampus and striatum (Rodriguez et al., 1993). The virus is then rapidly cleared such that persistence does not develop and demyelination does not ensue. In contrast, mice of susceptible $\mathrm{H}-2^{\mathrm{s}, \mathrm{v}, \mathrm{q}, \mathrm{u}, \mathrm{r}}$ haplotypes develop similar acute encephalitis, but this is followed by incomplete clearance of the virus and subsequent chronic demyelinating disease in the spinal cord beginning 35-45 d after infection (Rodriguez and David, 1985). The mechanism of resistance to virus persistence and demyelination is dependent on the development of a rapid virus-specific class I-restricted cytotoxic lymphocyte response directed against viral capsid antigen (Lin et al., 1995). We tested whether genetic disruption of IL-6 would convert normally resistant $\mathrm{H}-2^{\mathrm{b}}$ mice to a susceptible phenotype. 
Theiler's virus-infected IL- $6^{-1-} \mathrm{H}-2^{\mathrm{b}}$ mice had similar survival rates compared with IL- $6^{+/+}$control mice (Fig. 2 A). Only 2 of 19 IL- $6^{-1-}$ H-2 ${ }^{\text {b }}$ mice died within 2 weeks of infection as compared with 0 of 15 IL- $6^{+/+} \mathrm{H}-2^{\mathrm{b}}$ mice. In addition both the $\mathrm{IL}_{-} 6^{-1-} \mathrm{H}-2^{\mathrm{b}}$ and $\mathrm{IL}-6^{+/+} \mathrm{H}-2^{\mathrm{b}}$ mice showed no clinical or neurologic deficits. Analysis of the spinal cord at $12 \mathrm{~d}$ after infection showed slightly more gray matter disease in IL- $6^{-1-} \mathrm{H}-2^{\mathrm{b}}$ mice as compared with IL- $6^{+/+} \mathrm{H}-2^{\mathrm{b}}$ mice, but this was not statistically significant (Table 1). Only small areas of demyelination were observed in both groups of mice. By $45 \mathrm{~d}$ after infection the virus was cleared, and minimal or no pathologic abnormalities were observed in the spinal cord of six IL- $6^{-1-} \mathrm{H}-2^{\mathrm{b}}$ mice and eight IL- $6^{+/+}$ mice. We conclude that genetic deletion of IL- 6 had no effect on the normal resistance to chronic virus persistence and demyelination observed in $\mathrm{H}-2^{\mathrm{b}}$ mice.

\section{IL-6 disruption in susceptible $\mathrm{H}-2^{\mathrm{q}}$} mice results in marked clinical deficits and early death after Theiler's virus infection

To address the function of IL- 6 in animals of susceptible haplotype, we crossed IL- $6^{-1-} \mathrm{H}-2^{\mathrm{b}}$ mice to B10.Q mice. An $\mathrm{F}_{2}$ generation was produced, and animals homozygous for IL- $6^{-1-}$ and $\mathrm{H}-2^{\mathrm{q}}$ were selected. These mice were intercrossed to generate a line of IL- $6^{-1-} \mathrm{H}-2^{\mathrm{q}}$ mice and a line of IL- $6^{+/+} \mathrm{H}-2^{\mathrm{q}}$ mice. After Theiler's virus infection, IL- $6^{-1-} \mathrm{H}-2^{\mathrm{q}}$ mice showed a dramatic decrease in survival compared with IL- $6^{+/+} \mathrm{H}-2^{\mathrm{q}}$ mice. Seventeen of 29 IL- $6^{-1-}$ H-2 ${ }^{\mathrm{q}}$ mice died by 2 weeks after infection (Fig. 2A). Most deaths occurred during the first $12 \mathrm{~d}$ after infection. This implies that animals were likely dying as a result of the early neuronal disease seen with this model. In contrast, only 3 of 23 IL $-6^{+/+}$H-2 ${ }^{\mathrm{q}}$ mice were dead by 2 weeks $(p<0.05$ by $z$ test $)$. These animals also showed major clinical deficits characterized by uncoordination, motor hindlimb weakness or paralysis, scruffy fur, and poor general appearance (Fig. 2B). Approximately $40 \%$ of the mice survived until day 45 , a time point traditionally used in this model to determine the presence or absence of chronic demyelinating disease (Rodriguez et al., 1986b). Those mice that survived the acute neuronal disease exhibited significant improvement.

\section{IL-6 ${ }^{-/-}$mice develop humoral immune responses directed against Theiler's virus}

IL-6 has been shown to play an important role in the differentiation of B cells, and thus deficiency of this cytokine from birth could theoretically affect the protective humoral response directed against Theiler's virus and lead to reduced survival and enhancement of clinical deficits (Tosato et al., 1988; Strestik et al., 2001). To test this possibility we assessed antibody responses in the serum by ELISA directed against purified virus antigens (Fig. 3). Serum IgM and IgG responses were measured at 12 and $45 \mathrm{~d}$ after infection. At $12 \mathrm{~d}$ after infection both IL- $6^{-1-}$ and IL- $6^{+/+} \mathrm{H}-2^{\mathrm{b}}$ mice had titered antibody response against the virus. Similar IgM responses were observed in IL- $6^{-1-} \mathrm{H}-2^{\mathrm{q}}$ mice compared with IL- $6^{+/+} \mathrm{H}-2^{\mathrm{q}}$ mice. To address this further, we analyzed virus-specific neutralization us- ing antiserum from IL- $6^{+/+} \mathrm{H}-2^{\mathrm{q}}$ and IL- $6^{-/-} \mathrm{H}-2^{\mathrm{q}}$ mice at this time point. No difference in virus neutralization between the groups was identified. By $45 \mathrm{~d}$ after infection, both IL- $6^{+/+}$and IL-6 $6^{-1-}$ mice had higher serum IgG directed against the virus as compared with IL- $6^{+/+} \mathrm{H}-2^{\mathrm{b}}$ or IL- $6^{-/-} \mathrm{H}-2^{\mathrm{b}}$ mice. We conclude from these experiments that a deficit in IL- 6 did not affect the normal humoral response to Theiler's virus.

\section{IL-6-deficient mice after infection with Theiler's virus show normal distribution of CD4 and CD8 T cells and expression of class I and class II MHC antigens in the CNS}

We next asked whether IL-6 deficiency in $\mathrm{H}-2^{\mathrm{q}}$ mice altered the distribution of T cells or the expression of MHC in the CNS after virus infection. Immunostaining was performed on six IL- $6^{-/-}$and three IL- $6^{+/+}$mice. CD4 and CD8 T cells were observed in the spinal cord and brain of both strains of mice (Fig. 4). As described previously (Lindsley and Rodriguez, 1989), CD4 cells were found mostly in a perivascular location, whereas CD8 T cells were scattered away from blood vessels throughout the parenchyma. Class I MHC immunostaining was distributed within the lesion in blood vessels and in cells with presumed glial morphology. Class II MHC immunostaining was expressed in cells with morphology consistent with macrophages and microglia. No difference in the distribution or intensity of the staining was observed between IL- $6^{-/-}$and IL- $6^{+/+}$ mice. Previous experiments using FACS have demonstrated that the relative frequency of CD4 cells to CD8 and natural killer (NK) cells is an indicator of infiltrating cell distributions in the brain of TMEVinfected mice (Johnson et al., 2001). Using this methodology we found no differences in CD8 cells, NK cells, or macrophages in the brains of infected IL6 ${ }^{-1-} \mathrm{H}-2^{\mathrm{q}}$ mice compared with infected IL6 $^{+/+} \mathrm{H}-2^{\mathrm{q}}$ mice. We therefore conclude that adaptive immunity in IL6 ${ }^{-1-} \mathrm{H}-2^{\mathrm{q}}$ mice was not impaired.

\section{Chemokine expression is not changed in the CNS of} IL-6-deficient mice after infection

Previous studies have shown that antibody-mediated blockade of IP-10 drastically increases the mortality of mice infected intrace- 

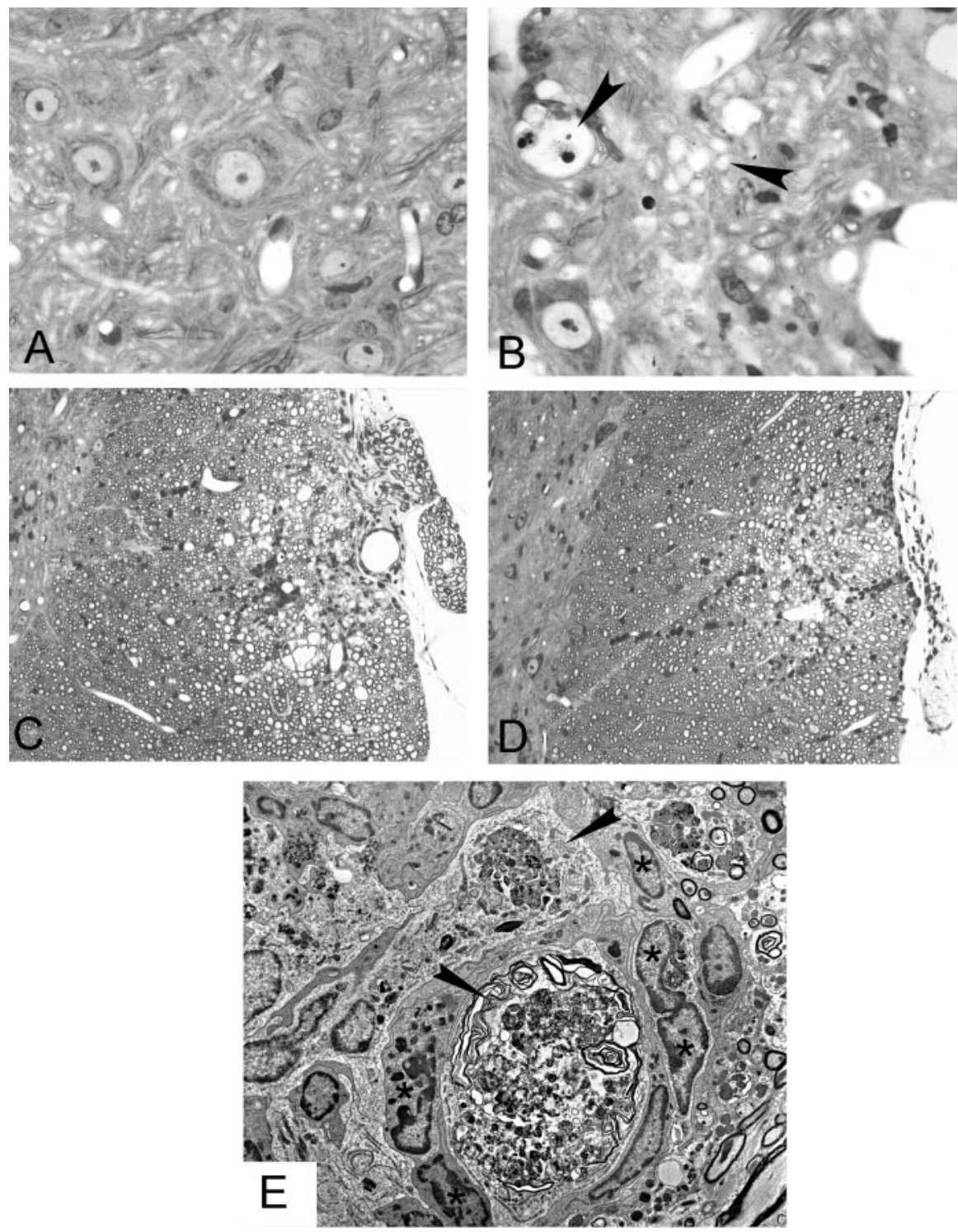

Figure 6. Pathologic analysis of spinal cord blocks embedded in plastic. Sections shown in $A-D$ were postfixed in osmium and stained with modified erichrome/cresyl violet stain. A, Anterior horn cells from an IL- $6^{+/+} \mathrm{H}-2^{9}$ mouse infected with Theiler's virus for $12 \mathrm{~d}$ show normal morphology $(900 \times)$. B, Vacuolar changes (arrowheads) in anterior horn cells from an IL-6 ${ }^{-1-} \mathrm{H}-2^{q}$ mouse infected for $12 \mathrm{~d}(900 \times)$. C, Focal area of demyelination and inflammatory infiltrates in the white matter of the spinal cord in an IL- $6^{+/+} \mathrm{H}-2^{9}$ mouse $45 \mathrm{~d}$ after infection $(300 \times)$. D, Similar area of demyelination and inflammation in an IL- $6^{-1-} \mathrm{H}-2^{\mathrm{q}}$ mouse $45 \mathrm{~d}$ after infection. ( $300 \times)$. E, Electron microscopy of the gray matter of an IL- $6^{-1-} \mathrm{H}-2^{9}$ mouse infected for $12 \mathrm{~d}$ shows degenerating neurons (arrowheads) surrounded by inflammatory cells (asterisks) $(2500 \times)$.

rebrally with mouse hepatitis virus (Liu et al., 2000), leading to the proposal that chemokines serve as essential sentinel molecules during the innate response of the CNS to viral infection (Asensio and Campbell, 2001). Furthermore, chemokine expression in models of innate immunity, such as the cutaneous air pouch, were found to be contingent on IL-6 signaling (Romano et al., 1997). Expression of chemokines during TMEV is tightly associated with pathogenesis (Murray et al., 2000) and is independent of the presence of CD4+ or CD8 $+\mathrm{T}$ cells (Ransohoff et al., 2001). Therefore, chemokines implicated in both antiviral responses (IP-10, RANTES) and wound repair (MCP-1) were monitored during TMEV disease in $\mathrm{H}-2^{\mathrm{q}}$ and $\mathrm{H}-2^{\mathrm{b}}$ mice that possessed or lacked IL-6. In susceptible and resistant mice, expression of all three chemokines was at least as vigorous in IL- $6^{-1-} \mathrm{H}-2^{\mathrm{q}}$ as observed in $\mathrm{IL}-6^{+/+} \mathrm{H}-2^{\mathrm{q}}$ mice, demonstrating a lack of dependence on IL-6 (Fig. 5) (data not shown). In the resistant $\mathrm{H}-2^{\mathrm{b}}$ strain, expression of all three chemokines in both brain and spinal cords was virtually identical in $\mathrm{IL}-6^{+/+} \mathrm{H}-2^{\mathrm{b}}$ mice and IL-6-null mice (data not shown). Susceptible IL$6^{-1-} \mathrm{H}-2^{9}$ mice expressed more MCP-1 and RANTES in the affected spinal cord than did IL- $6^{+/+} \mathrm{H}-2^{\mathrm{q}}$ mice (Fig. 5). As observed previously, expression of chemokines associated with an antiviral Th1 response (IP-10 and RANTES) was much more robust than expression of MCP-1 (Ransohoff et al., 2001). These results indicate that the innate response of the CNS to TMEV was not directly governed by IL- 6 or indirectly impaired in its absence.

\section{IL-6 ${ }^{-1-} \mathrm{H}-2^{\mathrm{q}}$ mice show severe pathology in the gray matter of the spinal cord at $\mathbf{1 2} \mathrm{d}$ after infection}

Given the absence of differences in innate and adaptive immune responses in these animals, we undertook a detailed morphologic analysis of IL- $6^{-1-} \mathrm{H}-2^{9}$ and IL- ${ }^{+1+} \mathrm{H}-2^{\mathrm{q}}$ mice at $12 \mathrm{~d}$ after infection to investigate the reason for the high death rate in the IL- $6^{-1-} \mathrm{H} 2^{\mathrm{q}}$ mice (Table 1). At this time point many of the mice were clinically ill or moribund. We found a twofold increase in the spinal cord quadrants with gray matter disease (13.5 \pm 3.8 in $\mathrm{IL}-6^{-1-} \mathrm{H}-2^{\mathrm{q}}$ mice as compared with $5.3 \pm 1.0$ in ${\mathrm{IL}-6^{+/+}}^{+1}$ $\mathrm{H}-2^{\mathrm{q}}$ mice; $p<0.05$ by $t$ test). In addition there was increased meningeal inflammation and early demyelination, although this did not reach significance. Multiple examples of anterior horn neurons undergoing cell death were also observed (Fig. 6B). Neurophagia, as demonstrated by macrophages and other inflammatory cells engulfing neuronal debris, was observed in IL- $6^{-1-} \mathrm{H}-2^{9}$ mice but not in the IL- $6^{+/+} \mathrm{H}-2^{9}$ controls. By electron microscopy these dying neurons showed vacuolar changes in the cytoplasm without early changes in the nuclei (Fig. $6 E$ ). We were also able to study $10 \mathrm{IL}-6^{-1-} \mathrm{H}-2^{\mathrm{q}}$ and $10 \mathrm{IL}-6^{+/+} \mathrm{H}-2^{\mathrm{q}}$ mice that survived to $45 \mathrm{~d}$ after infection. IL- $6^{+/+} \mathrm{H}-2^{\mathrm{q}}$ (Fig. 6C) and IL-6 ${ }^{-1-} \mathrm{H}-2^{\mathrm{q}}$ (Fig. 6D) mice showed demyelination in the spinal cord, and the extent and distribution of demyelination were not different between the two groups (Table 1). The extent of gray matter disease was greater, however, in IL- $6^{-/-}$mice compared with IL- $6^{+/+}$. The number of quadrants demonstrating meningeal inflammation was reduced in IL- $6^{-1-} \mathrm{H}-2^{\mathrm{q}}$ mice, indicating that one of the primary reasons that IL- $6^{-1-} \mathrm{H}-2^{\mathrm{q}}$ mice experienced marked neurologic deficits and early deaths was likely caused by injury of anterior horn cells in the gray matter of the spinal cord. 


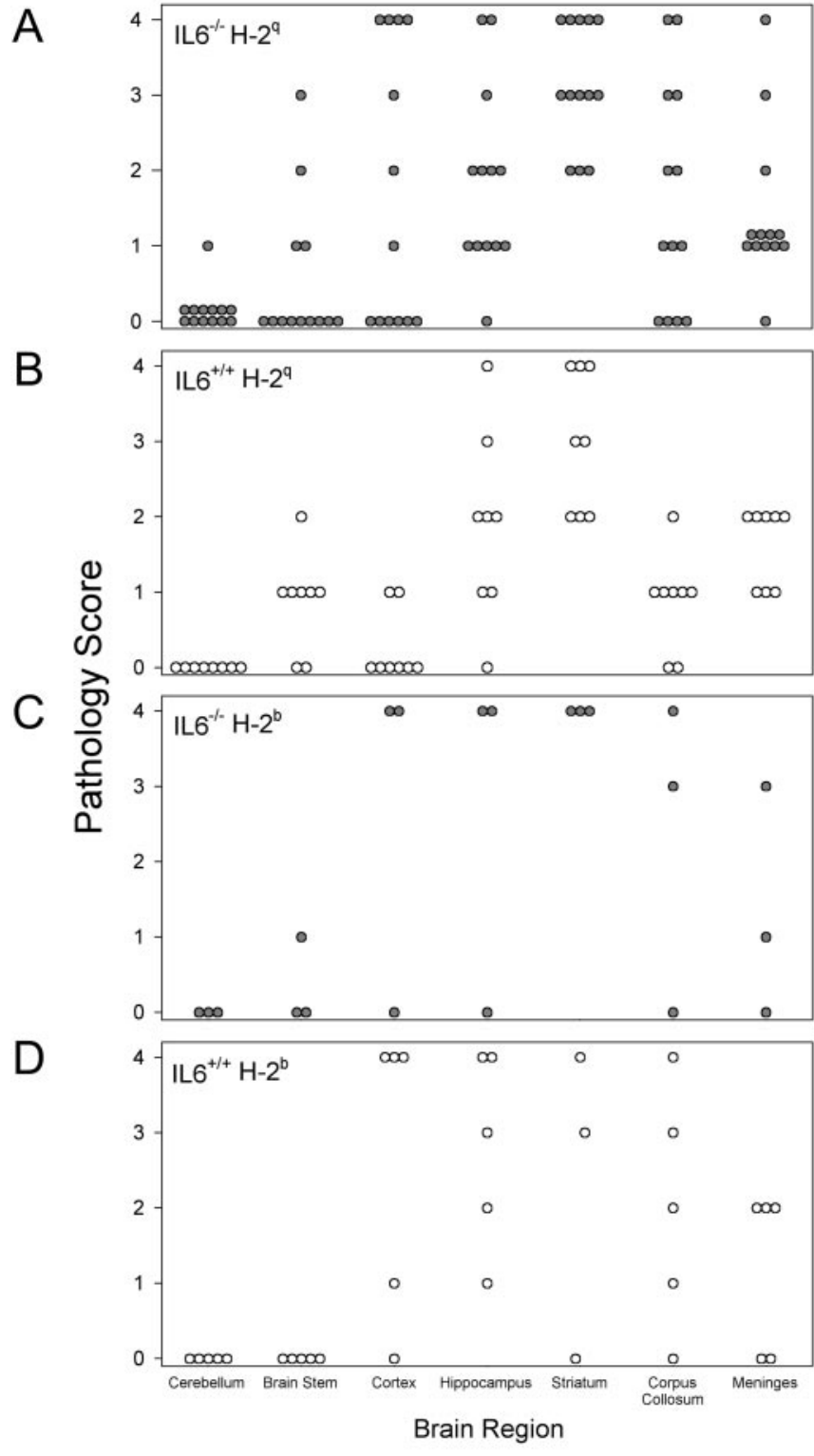

Figure 7. Pathologic analysis after $12 \mathrm{~d}$ of infection of brain areas (cerebellum, brain stem, cortex, hippocampus, striatum, corpus callosum, and meninges) of IL- $6^{-1-} \mathrm{H}-2^{9}$ mice $(A)$, $\mathrm{IL}-6^{+/+} \mathrm{H}-2^{\mathrm{a}}$ mice $(B), \mathrm{IL}-6^{-1-} \mathrm{H}-2^{\mathrm{b}}$ mice $(C)$, and IL- $6^{-1-} \mathrm{H}-2^{\mathrm{b}}$ mice $(D)$. Pathology qualitative scores from 0 to 4 are described in Materials and Methods. Each circle represents one mouse. Note the increased severity of brain pathology in $\mathrm{H}-2^{\mathrm{a}}$ mice as compared with $\mathrm{H}-2^{\mathrm{b}}$ mice regardless of IL-6 expression. More severe cortical disease was observed in IL-6 ${ }^{-1-} \mathrm{H}-2^{9}$ mice as compared with IL- $6^{+/+} \mathrm{H}-2^{q}$ mice after $12 \mathrm{~d}$ of Theiler's virus infection $(p<0.05)$.

Theiler's virus-infected IL- $6^{-/-} \mathrm{H}-2^{\mathrm{q}}$ mice show more severe disease in the cortex of the brain

We asked whether deficiency in IL- 6 would predispose specific populations of brain neurons to virus-induced injury. We analyzed the brains of IL- $6^{-1-} \mathrm{H}-2^{\mathrm{b}}, \mathrm{IL}-6^{+/+} \mathrm{H}-2^{\mathrm{b}}, \mathrm{IL}-6^{-1-}$ $\mathrm{H}-2^{\mathrm{q}}$, and IL- $6^{+/+} \mathrm{H}-2^{\mathrm{q}}$ mice for severity of pathologic injury to areas of the brain (Fig. 7). We used a semiquantitative four-point scale for analysis. On average, $\mathrm{H}-2^{\mathrm{q}}$ mice showed greater severity of brain pathology than $\mathrm{H}-2^{\mathrm{b}}$ mice regardless of IL-6 expression; however, a higher proportion of IL-6 $6^{-1-}$ $\mathrm{H}-2^{\mathrm{q}}$ mice had severe disease in the cortex as compared with IL- $6^{+/+} \mathrm{H}-2^{\mathrm{q}}$ mice $(p<0.05$ by $z$ test). Of interest, no major change in the severity of brain disease was observed in the cerebellum, brainstem, hippocampus, corpus callosum, or striatum, and the degree of meningeal inflammation was not altered. These results indicate that IL- 6 was necessary to protect specific populations of brain neurons against virusinduced injury.

\section{IL- $6^{-/-} \mathrm{H}-2^{\mathrm{q}}$ mice propagate more virus infection in the gray matter of the spinal cord}

We evaluated the level of virus infectivity, RNA expression, and virus antigen expression in $\mathrm{IL}-6^{+/+} \mathrm{H}-2^{\mathrm{b}}, \mathrm{IL}-6^{-1-} \mathrm{H}-2^{\mathrm{b}}$, IL$6^{+/+} \mathrm{H}-2^{\mathrm{q}}$, and IL- $6^{-1-} \mathrm{H}-2^{\mathrm{q}}$ mice at various time points after infection. Viral plaque assays that measure virus infectivity showed that $\mathrm{H}-2{ }^{\mathrm{q}}$ mice on average replicated 100 -fold more virus than $\mathrm{H}-2^{\mathrm{b}}$ mice regardless of IL- 6 expression (Fig. $8 A$ ). The number of viral plaques per gram of CNS was not different between IL- $6^{-1-}$ and IL- $6^{+/+}$mice at $7 \mathrm{~d}$ after infection when the entire CNS was assayed. To address more precisely where virus was replicating, we used immunoperoxidase staining with an antibody specific for virus antigen. The number of virus antigenpositive cells at $12 \mathrm{~d}$ after infection was expressed as a function of the area of either spinal cord white matter or gray matter (Fig. $8 B)$. In IL- $6^{+/+} \mathrm{H}-2^{\mathrm{q}}$ mice, the number of virus antigen-positive cells was similar in both spinal cord white matter and gray matter. In contrast, in IL- $6^{-1-} \mathrm{H}-2^{9}$ mice there was an eightfold increase in the number of virus antigen-positive cells in the gray matter versus the white matter. To confirm this observation we further measured virus-specific RNA (Fig. 8C) by Northern blot. VP2 cDNA, one of the major capsid proteins, was used to probe virus RNA as compared with GAPDH as an internal standard. The data were expressed as the ratio of VP2 to GAPDH. In IL- ${ }^{+/+} \mathrm{H}-2^{\mathrm{q}}$ mice the level of virus RNA was similar in the brain and spinal cord at day 7 after infection. By day 12 the amount of virus RNA decreased dramatically in both the brain and spinal cord. In IL$6^{-1-} \mathrm{H}-2^{\mathrm{q}}$ mice, similar levels of virus RNA were observed in the brain and spinal cord at day 7 , and these levels were comparable with those observed in IL- $6^{+/+} \mathrm{H}-2^{\mathrm{q}}$ mice. In contrast, on day 12 after infection there was a 20 -fold increase in virus-specific RNA in the spinal cord compared with the brain ( $p<0.05$ by $t$ test). In addition, although it did not reach significance (NS by rank sum), virus antigen in the gray matter of IL- $6^{-1-} \mathrm{H}-2^{\mathrm{q}}$ mice was increased compared with IL- $6^{+/+} \mathrm{H}-2^{\mathrm{q}}$ mice. Both the analysis of virus antigen-positive cells and the Northern blot data support the conclusion that IL-6 deficiency allowed for robust virus replication in the gray matter of the spinal cord.

\section{IL-6 deficiency permits prominent virus infection of anterior horn motor neurons in the spinal cord}

We examined which cells in the nervous system were expressing virus antigen in IL- $6^{+/+} \mathrm{H}-2^{\mathrm{q}}$ and IL- $6^{-1-} \mathrm{H}-2^{\mathrm{q}}$ mice $12 \mathrm{~d}$ after infection (Fig. 9). In the brain of IL- $6^{-1-} \mathrm{H}-2^{\mathrm{q}}$ mice there was notable virus in the cortex, hippocampus, and striatum; however, the most unique finding was the localization of virus within the anterior horn cells of the spinal cord. Virus antigen was localized exclusively to the cytoplasm of these cells. In many of these cells the morphology was sufficiently intact to identify the nucleoli. No examples of anterior horn motor neurons expressing virus antigen (analysis of 18 mice and 144 sections) were identified in the control mice. IL- $6^{+/+} \mathrm{H}-2^{\mathrm{q}}$ mice showed similar virus antigen staining in the brain as compared with IL- $6^{-1-} \mathrm{H}-2^{\mathrm{q}}$ mice, with staining in the spinal cord gray matter limited to virus that was scattered among and engulfed by inflammatory cells. This provided strong evidence that the reason for high morbidity and 

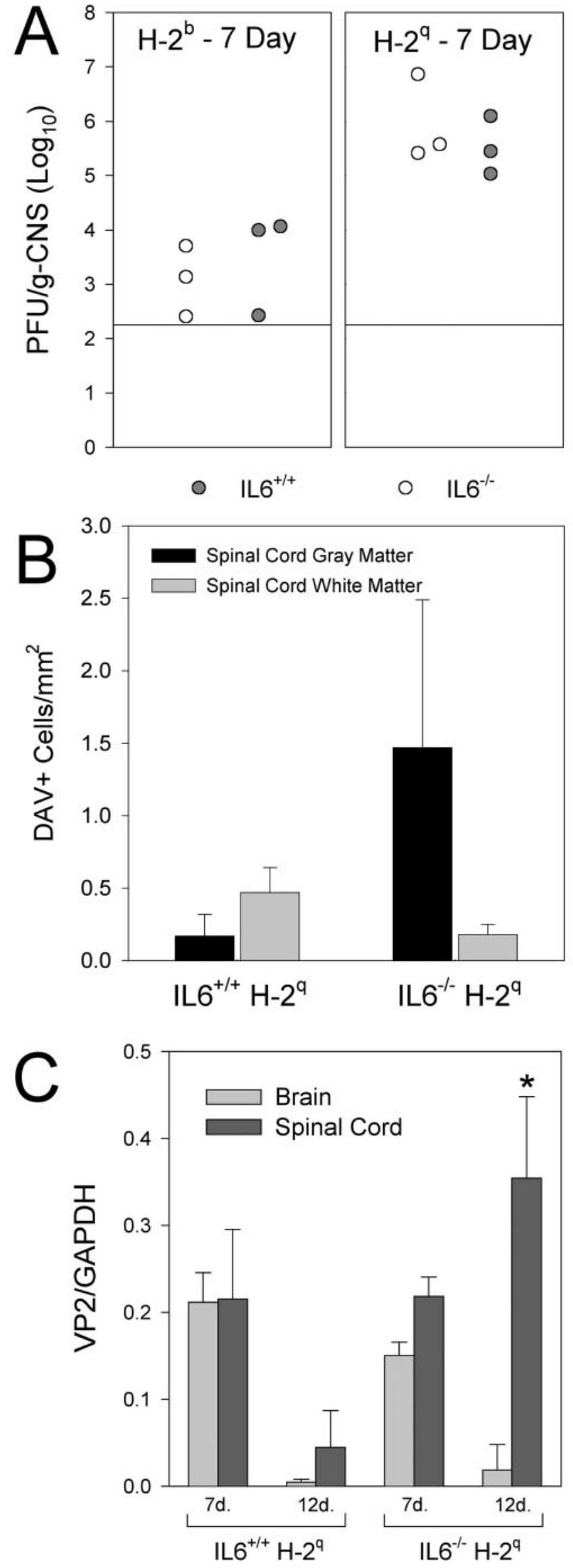

mortality in IL- $6^{-1-} \mathrm{H}-2^{9}$ mice was prominent infection of motor neurons in the spinal cord.

\section{IL-6 protects motor neurons from virus-induced death in vitro}

NSC-34 cells, under appropriate culture conditions, display a well characterized motor neuron phenotype (Cashman et al., 1992; Eggett et al., 2000). We used these cells to directly test the hypothesis that IL-6 protects motor neurons from virus-induced death. Infection with 1.5 pfu of TMEV per cell induced the death of $45 \%( \pm 1.0 \% ; p<0.05)$ of NSC-34 cells after $24 \mathrm{hr}$. Treatment with $1 \mathrm{ng} / \mathrm{ml}$ of IL- 6 added at the time of infection rescued $10 \%$ $( \pm 2.9 \% ; p=0.009$ vs vehicle) more NSC-34 cells than vehicle alone (Fig. 10A). Likewise, $10 \mathrm{ng} / \mathrm{ml}$ of IL-6 rescued $21 \%$ $( \pm 2.7 \% ; p=0.002$ vs vehicle) more cells, and treatment with 100 $\mathrm{ng} / \mathrm{ml}$ of IL-6 rescued $30 \%( \pm 2.3 \% ; p=0.002$ vs vehicle $)$ more cells than vehicle only (Fig. $10 A$ ). Importantly, treatment with IL-6 in the absence of DAV infection did not induce cell proliferation at any concentration tested ( $p=0.83$ across all groups by ANOVA; data not shown).

On the basis of our findings in NSC-34 cells, we asked whether IL-6 protected primary motor neurons from DAV-induced cell death. Spinal motor neurons were isolated from neonatal C57BL/6J mice and cultured for 2 weeks in defined media. Cells were infected with 1.5 pfu of DAV per cell and treated either with $100 \mathrm{ng} / \mathrm{ml}$ IL-6 or with vehicle. After $24 \mathrm{hr}$, cell survival was measured with the MTT assay and compared with uninfected cultures. As shown in Figure 10 B, $77.4 \pm 7.8 \%(n=3 ; p=0.042$ vs vehicle) of motor neurons survived in the IL-6-treated DAVinfected cultures, whereas treatment with only vehicle supported the survival of $51.6 \pm 0.5 \%(n=3)$ of motor neurons. Hence, we conclude that the enhanced mortality and pathology observed in IL- $6^{-1-} \mathrm{H}-2^{\mathrm{q}}$ mice were the result of a deficit in neuroprotection normally afforded by the presence of IL- 6 in astrocytes.

\section{Discussion}

Our results suggest that IL- 6 is critical for protecting specific neuronal populations in the spinal cord and brain from cell death induced by infection with Theiler's virus. Disruption of IL-6 in normally resistant $\mathrm{H}-2^{\mathrm{b}}$ mice had no effect on virus-induced injury of neurons. These mice cleared the virus infection normally, likely as a result of a vigorous antiviral class I-restricted cytotoxic lymphocyte response (Borson et al., 1997; Dethlefs et al., 1997). In contrast, when we crossed IL-6-deficient mice with susceptible $\mathrm{H}-2^{\mathrm{q}}$ mice, these animals showed early death and prominent infection in the gray matter of the spinal cord. The

\section{$\leftarrow$}

Figure 8. Levels of virus infectivity, antigen expression, and RNA expression in IL-6 ${ }^{-1-}$ and IL- $6^{+/+}$mice. $A$, Virus infectivity as measured by plaque assay is expressed as the number of plaque-forming units per gram of total CNS (brain and spinal cord). On average there was a $\sim 100$-fold increase in plaque-forming units in $\mathrm{H}-2^{\mathrm{q}}$ mice compared with $\mathrm{H}-2^{\mathrm{b}}$ at $7 \mathrm{~d}$ after infection regardless of IL-6 expression. $B$, The number of virus antigen-positive cells was determined by immunoperoxidase staining and expressed per square millimeters of spinal cord gray matter or white matter area. No difference was observed in the number of virus antigenpositive cells in the white matter when comparing IL- $6^{-1-} \mathrm{H}-2^{9}$ mice as compared with $\mathrm{IL}-6^{+/+}$mice. More virus antigen-positive cells were observed in the spinal cord gray matter of $\mathrm{IL}-6^{-1-} \mathrm{H}-2^{q}$ mice as compared with IL- ${ }^{+/+} \mathrm{H}-2^{q}$ mice; however, this did not reach statistical significance. C, Levels of viral capsid VP2 RNA message were analyzed by Northern blot as a function of GAPDH message. In IL- $6^{+/+} \mathrm{H}-2^{9}$ mice, the level of VP2 message was similar in the brain and spinal cord on day 7 , and both were decreased by $12 \mathrm{~d}$ after infection. In contrast, in IL- $6^{-1-} \mathrm{H}-2^{\mathrm{q}}$ mice the level of VP2 message was similar in the brain and spinal cord at $7 \mathrm{~d}$ after infection, whereas at $12 \mathrm{~d}$ a dramatic increase in VP2 message was observed in the spinal $\operatorname{cord}(p<0.05$ by $t$ test). 
severe virus-induced injury to anterior horn motor neurons in IL-6 $6^{-1-} \mathrm{H}-2^{\mathrm{q}}$ mice is the likely explanation for the clinical phenotype that we observed. Of interest is the mechanism by which IL-6, a multipotential cytokine with functions that are not confined to the immune and hematopoietic systems, protects neurons from injury (Hama et al., 1989; Ramsay et al., 1994; Zhong et al., 1999). We have considered four possibilities for how IL-6 deficiency may result in severe neuronal injury after virus infection.

The first possibility is that IL-6 deficiency affects the antiviral humoral response such that neutralizing antibodies are not generated. We addressed this hypothesis using virus-specific ELISA for both the $\operatorname{IgM}$ and $\operatorname{IgG}$ response in mice with or without disruption of IL-6 in both the $\mathrm{H}-2^{\mathrm{q}}$ and $\mathrm{H}-2^{\mathrm{b}}$ haplotype. Although IL- 6 has been shown to exert a strong influence on maturation and differentiation of B cells (Roldan and Brieva, 1991; Roldan et al., 1992; Kopf et al., 1998), no effect was observed in the viral-specific antibody responses. To explore this further we examined the neutralization of virus with antiserum from IL- $6^{-1-} \mathrm{H}-2^{\mathrm{q}}$ or IL- $6^{+/+} \mathrm{H}-2^{\mathrm{q}}$ mice infected with TMEV for $12 \mathrm{~d}$. Titers confirmed that there were no differences in the ability of the serum
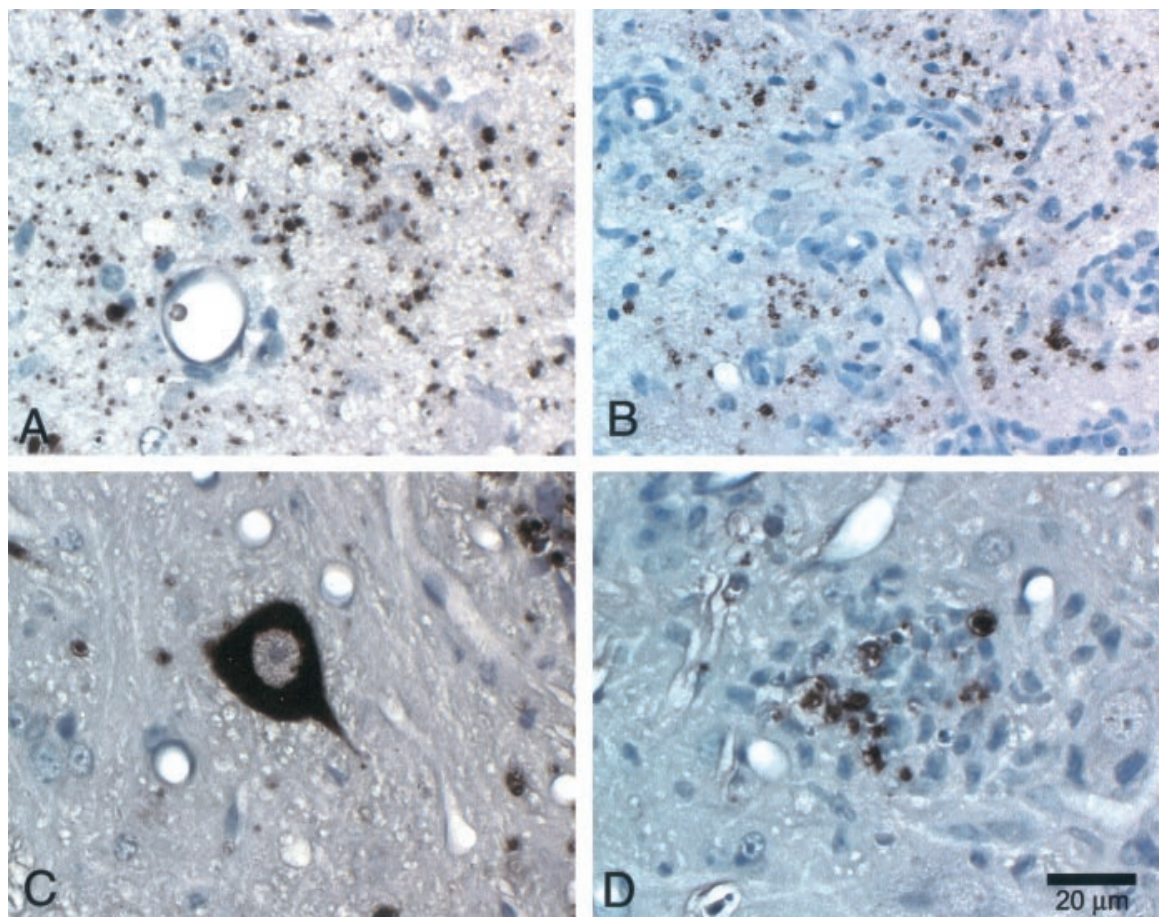

Figure 9. Immunoperoxidase staining for virus antigen using a polyclonal rabbit antiserum that reacts strongly with all the structural viral capsid proteins of Theiler's virus (Rodriguez et al., 1983). A, Low magnification (300X) image from the cortex and hippocampus showing multiple antigen-positive cells in an IL-6 $6^{-1-} \mathrm{H}-2^{9}$ mouse infected with TMEV for $12 \mathrm{~d}$. B, A similar staining pattern was seen in the cortex and hippocampus of the infected IL- $6^{+/+} \mathrm{H}-2^{9}$ mice. C, Virus antigen within anterior horn cells of the spinal cord of an IL- $6^{-1-}$ $\mathrm{H}-2^{9}$ mouse. Virus is localized exclusively to the cytoplasm of the neuron. No similar virus antigen-positive anterior horn cell neurons were identified in infected IL- $6^{+/+} \mathrm{H}-2^{9}$ mice. D, Virus antigen localized to the spinal cord gray matter of an infected IL- $6^{+/+} \mathrm{H}-2^{9}$ mouse. Virus antigen is associated primarily with inflammatory cells and presumed macrophages.

from either strain to neutralize the virus.

Our data indicate that the generation of a neutralizing antibody response to TMEV is independent of IL-6.

The second possibility is that IL-6 deficiency altered the cellular inflammatory response to virus injury (Sarawar et al., 1998; Wang et al., 2000). IL-6, IL-1, and TNF can be released by activated monocytes. These cytokines are part of the acute injury response to foreign antigens and viral infection (Conn et al., 1995). IL-6 has been shown to be crucial for recruitment of myelomonocytes and activation of glial cells after focal cryo-injury of the frontoparietal cortex (Penkowa et al., 1999). IL-6 ${ }^{-/-}$mice have impaired leukocyte accumulation in target tissues as a result of reduced in situ production of chemokines (Romano et al., 1997), and are highly susceptible to Listeria monocytogenes, probably as a result of inefficient neutrophilia (Dalrymple et al., 1995). IL-6 ${ }^{-1-}$ mice have reduced myocardial damage after infection of encephalomyocarditis virus, and this is likely mediated via modification of the immune response (Kanda et al., 1996). In the gammaherpes-

virus-68 model in mice, however, no differences were observed in IL-6-deficient mice in regard to number or activation status of leukocytes (Sarawar et al., 1998). Thus the IL-6 system may or may not have a role in local inflammatory reactions. To address this issue we examined CD4 and CD8 infiltrates, as well as class I and class II expression in IL- $6^{-/-} \mathrm{H}-2^{\mathrm{q}}$ mice as compared with IL- $6^{+/+} \mathrm{H}-2^{\mathrm{q}}$ mice at $12 \mathrm{~d}$ after infection. No differences were detected by immunoperoxidase staining or by FACS analysis. In addition, we analyzed RNA expression of various chemokines in the CNS of these mice. At $12 \mathrm{~d}$ after infection, chemokine expression in the CNS of susceptible mice that lacked IL-6 was extremely robust, demonstrating that innate responses to viral chal- lenge were not deficient in IL-6-null mice. This observation suggests that CNS cellular immune host defense is not contingent on the presence of IL- 6 in $\mathrm{H}-2^{\mathrm{q}}$ mice.

The third possibility is that IL-6-deficient mice develop the lethal phenotype after virus infection because of a lack of antiviral activity. IL-6 was initially discovered because of biologic effects similar to interferon $\beta$; however, previous in vitro experiments treating Theiler's virus-infected cells with various concentrations

of IL-6 showed no direct antiviral effect on the growth of this picornavirus (Rodriguez et al., 1994). In addition, in the present experiments there were no differences in infectious viral titers from the CNS of IL- $6^{-/-}$mice as compared with IL- $6^{+/+}$mice; however, more virus RNA replication was observed in the gray matter of the spinal cord in IL- $6^{-1-} \mathrm{H}-2^{\mathrm{q}}$ mice. Therefore, it is possible that IL-6 is working to limit virus spread in the anterior horn.

We, however, favor the possibility that IL-6 is working to support the survival of specific neuronal populations. Previous experiments on primary CNS cultures from susceptible and resistant animals show no difference in TMEV binding (Rubio et al., 1990). Therefore, we isolated primary spinal motor neurons from C57BL/ 6 mice and tested whether IL- 6 could protect these cells from TMEV infection. This data further supported our data on NSC-34 motor neurons which indicate that IL-6 protects from cell death induced by infection with Theiler's virus, and we hypothesize that IL-6 is functioning in a similar manner in vivo to protect anterior horn motor neurons from virus-induced death. Further support for this hypothesis is provided by the finding that IL-6 enhances the survival of septal cholinergic neurons and 
A

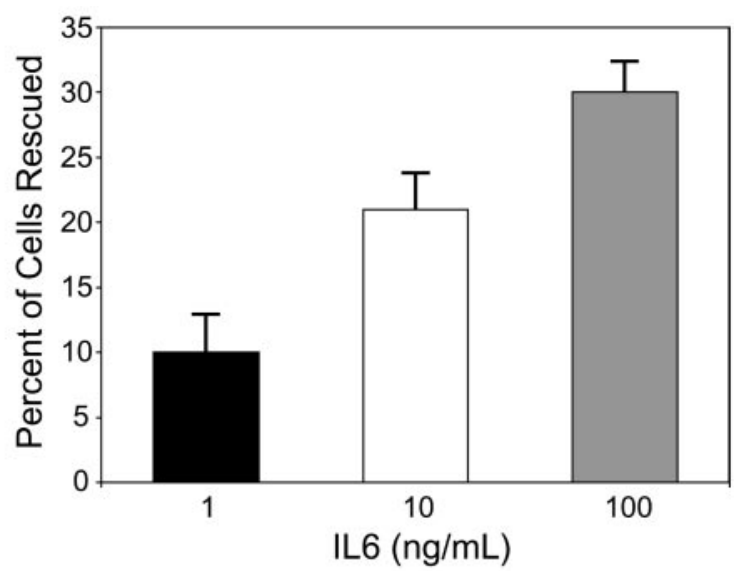

B

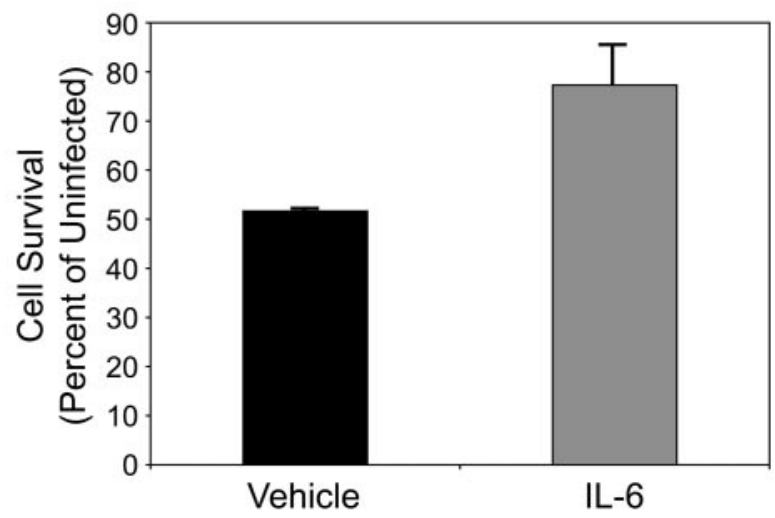

Figure 10. IL-6rescues NSC-34 motor neurons and primary spinal motor neurons infected in culture with Theiler's virus. A, NSC-34 cells were infected with $1.5 \mathrm{pfu}$ of virus per cell for $24 \mathrm{hr}$ in the presence or absence of various concentrations of IL-6. Treatment with $1 \mathrm{ng} / \mathrm{ml}$ of IL-6 added at the time of infection rescued $10 \%( \pm 2.9 \% ; p=0.009$ vs vehicle) more NSC-34 cells than vehicle alone. Similarly, $10 \mathrm{ng} / \mathrm{ml}$ of IL-6 rescued $21 \%( \pm 2.7 \% ; p=0.002$ vs vehicle) more cells, and treatment with $100 \mathrm{ng} / \mathrm{ml} \mathrm{IL-6}$ rescued $30 \%$ ( $\pm 2.3 \% ; p=0.002$ vs vehicle) more cells than vehicle only. $B$, Primary spinal motor neurons were infected with $1.5 \mathrm{pfu}$ of virus per cell, and cultures were concomitantly treated with $100 \mathrm{ng} / \mathrm{ml}$ of IL-6 or with vehicle. After 24 $\mathrm{hr}$, cell survival was measured by MTT assay and normalized to uninfected cultures. Although only $51.6 \pm 0.5 \%$ of spinal motor neurons survived in vehicle-treated cultures, IL-6-treated cultures exhibited survival of $77.4 \pm 7.8 \%$ ( $p=0.042$ vs vehicle) of motor neurons.

acetylcholinesterase-positive neurons in culture (Hama et al., 1989). Of particular interest, IL-6 can rescue spinal motor neurons from axotomy-induced cell death, and an IL-6/sIL-6R fusion protein has been shown to promote neurite outgrowth and neuron survival in cultured enteric neurons (Schafer et al., 1999). Likewise, in vivo coadministration of IL-6 and soluble IL-6 receptor delays progression of wobbler mouse motor neuron disease (Ikeda et al., 1996). Importantly, IL-6 has been shown to be produced by astrocytes during acute neurotropic coronavirus infection (Sun et al., 1995), and reactive oxygen-free radicals can enhance the transcription of IL-6 by astrocytes (Maeda et al., 1994). Thus, we propose that the release of IL-6 from astrocytes exerts a neuroprotective effect that prevents the lethal injury of anterior horn spinal motor neurons after infection with Theiler's virus.

\section{References}

Akira S (1997) IL-6-regulated transcription factors. Int J Biochem Cell Biol 29:1401-1418.

Asensio VC, Campbell IL (2001) Chemokines and viral diseases of the central nervous system. Adv Virus Res 56:127-173.
Borson ND, Paul C, Lin X, Nevala WK, Strausbauch MA, Rodriguez M, Wettstein PJ (1997) Brain-infiltrating cytolytic T lymphocytes specific for Theiler's virus recognize $\mathrm{H} 2 \mathrm{Db}$ molecules complexed with a viral VP2 peptide lacking a consensus anchor residue. J Virol 71:5244-5250.

Carlson NG, Wieggel WA, Chen J, Bacchi A, Rogers SW, Gahring LC (1999) Inflammatory cytokines IL-1 alpha, IL-1 beta, IL-6, and TNF-alpha impart neuroprotection to an excitotoxin through distinct pathways. J Immunol 163:3963-3968.

Cashman NR, Durham HD, Blusztajn JK, Oda K, Tabira T, Shaw IT, Dahrouge S, Antel JP (1992) Neuroblastoma x spinal cord (NSC) hybrid cell lines resemble developing motor neurons. Dev Dyn 194:209-221.

Conn CA, McClellan JL, Maassab HF, Smitka CW, Majde JA, Kluger MJ (1995) Cytokines and the acute phase response to influenza virus in mice. Am J Physiol 268:R78--R84.

Dalrymple SA, Lucian LA, Slattery R, McNeil T, Aud DM, Fuchino S, Lee F, Murray R (1995) Interleukin-6-deficient mice are highly susceptible to Listeria monocytogenes infection: correlation with inefficient neutrophilia. Infect Immunol 63:2262-2268.

Dethlefs S, Escriou N, Brahic M, van der Werf S, Larsson-Sciard EL (1997) Theiler's virus and Mengo virus induce cross-reactive cytotoxic T lymphocytes restricted to the same immunodominant VP2 epitope in C57BL/6 mice. J Virol 71:5361-5365.

Drescher KM, Rivera-Quinones C, Lucchinetti CF, Rodriguez M (1998) Failure of treatment with Linomide or oral myelin tolerization to ameliorate demyelination in a viral model of multiple sclerosis. J Neuroimmunol 88:111-119.

Drescher KM, Murray PD, David CS, Pease LR, Rodriguez M (1999) CNS cell populations are protected from virus-induced pathology by distinct arms of the immune system. Brain Pathol 9:21-31.

Eggett CJ, Crosier S, Manning P, Cookson MR, Menzies FM, McNeil CJ, Shaw PJ (2000) Development and characterization of a glutamate-sensitive motor neuron cell line. J Neurochem 74:1895-1902.

Hama T, Miyamoto M, Tsukui H, Nishio C, Hatanaka H (1989) Interleukin-6 as a neurotrophic factor for promoting the survival of cultured basal forebrain cholinergic neurons from postnatal rats. Neurosci Lett 104:340-344.

Ikeda K, Kinoshita M, Tagaya N, Shiojima T, Taga T, Yasukawa K, Suzuki H, Okano A (1996) Coadministration of interleukin-6 (IL-6) and soluble IL-6 receptor delays progression of wobbler mouse motor neuron disease. Brain Res 726:91-97.

Johnson AJ, Upshaw J, Pavelko KD, Rodriguez M, Pease LR (2001) Preservation of motor function by inhibition of CD8 + virus peptide-specific $\mathrm{T}$ cells in Theiler's virus infection. FASEB J 15:2760-2762.

Kanda T, McManus JE, Nagai R, Imai S, Suzuki T, Yang D, McManus BM, Kobayashi I (1996) Modification of viral myocarditis in mice by interleukin-6. Circ Res 78:848-856.

Kopf M, Baumann H, Freer G, Freudenberg M, Lamers M, Kishimoto T, Zinkernagel R, Bluethmann H, Kohler G (1994) Impaired immune and acute-phase responses in interleukin-6-deficient mice. Nature 368:339-342.

Kopf M, Herren S, Wiles MV, Pepys MB, Kosco-Vilbois MH (1998) Interleukin 6 influences germinal center development and antibody production via a contribution of C3 complement component. J Exp Med 188:1895-1906.

Lin X, Thiemann NR, Pease LR, Rodriguez M (1995) VP1 and VP2 capsid proteins of Theiler's virus are targets of H-2D-restricted cytotoxic lymphocytes in the central nervous system of B10 mice. Virology 214:91-99.

Lindsley MD, Rodriguez M (1989) Characterization of the inflammatory response in the central nervous system of mice susceptible or resistant to demyelination by Theiler's virus. J Immunol 142:2677-2682.

Lipton HL (1975) Theiler's virus infection in mice: an unusual biphasic disease process leading to demyelination. Infect Immunol 11:1147-1155.

Liu MT, Chen BP, Oertel P, Buchmeier MJ, Armstrong D, Hamilton TA, Lane TE (2000) The T cell chemoattractant IFN-inducible protein 10 is essential in host defense against viral-induced neurologic disease. J Immunol 165:2327-2330.

Maeda Y, Matsumoto M, Hori O, Kuwabara K, Ogawa S, Yan SD, Ohtsuki T, Kinoshita T, Kamada T, Stern DM (1994) Hypoxia/reoxygenationmediated induction of astrocyte interleukin 6: a paracrine mechanism potentially enhancing neuron survival. J Exp Med 180:2297-2308.

Middleton G, Hamanoue M, Enokido Y, Wyatt S, Pennica D, Jaffray E, Hay RT, Davies AM (2000) Cytokine-induced nuclear factor kappa B activa- 
tion promotes the survival of developing neurons. J Cell Biol 148:325-332.

Murray PD, Krivacic K, Chernosky A, Wei T, Ransohoff RM, Rodriguez M (2000) Biphasic and regionally-restricted chemokine expression in the central nervous system in the Theiler's virus model of multiple sclerosis. J Neurovirol 6[Suppl 1]:S44-S52.

Njenga MK, Pavelko KD, Baisch J, Lin X, David C, Leibowitz J, Rodriguez M (1996) Theiler's virus persistence and demyelination in major histocompatibility complex class II-deficient mice. J Virol 70:1729-1737.

Njenga MK, Asakura K, Hunter SF, Wettstein P, Pease LR, Rodriguez M (1997) The immune system preferentially clears Theiler's virus from the gray matter of the central nervous system. J Virol 71:8592-8601.

Penkowa M, Moos T, Carrasco J, Hadberg H, Molinero A, Bluethmann H, Hidalgo J (1999) Strongly compromised inflammatory response to brain injury in interleukin-6-deficient mice. Glia 25:343-357.

Pierce ML, Rodriguez M (1989) Erichrome stain for myelin on osmicated tissue embedded in glycol methacrylate plastic. J Histotechnol 12:35-36.

Ramsay AJ, Husband AJ, Ramshaw IA, Bao S, Matthaei KI, Koehler G, Kopf M (1994) The role of interleukin-6 in mucosal IgA antibody responses in vivo. Science 264:561-563.

Ransohoff RM, Wei T, Pavelko KD, Lee J-C, Murray PD, Rodriguez M (2001) Chemokine expression in the central nervous system of mice with a viral disease resembling multiple sclerosis: roles of CD4+ and CD8+ T-cells and viral persistence. J Virol 76:2217-2224.

Rodriguez M, David CS (1985) Demyelination induced by Theiler's virus: influence of the H-2 haplotype. J Immunol 135:2145-2148.

Rodriguez M, Leibowitz JL, Lampert PW (1983) Persistent infection of oligodendrocytes in Theiler's virus-induced encephalomyelitis. Ann Neurol 13:426-433.

Rodriguez M, Lafuse WP, Leibowitz J, David CS (1986a) Partial suppression of Theiler's virus-induced demyelination in vivo by administration of monoclonal antibodies to immune-response gene products (Ia antigens). Neurology 36:964-970.

Rodriguez M, Leibowitz J, David CS (1986b) Susceptibility to Theiler's virus-induced demyelination. Mapping of the gene within the H-2D region. J Exp Med 163:620-631.

Rodriguez M, Lindsley MD, Pierce ML (1991a) Role of T cells in resistance to Theiler's virus infection. Microb Pathog 11:269-281.

Rodriguez M, Nickerson C, Patick AK, David CS (1991b) Expression of human HLA-B27 transgene alters susceptibility to murine Theiler's virusinduced demyelination. J Immunol 146:2596-2602.

Rodriguez M, Dunkel AJ, Thiemann RL, Leibowitz J, Zijlstra M, Jaenisch R (1993) Abrogation of resistance to Theiler's virus-induced demyelination in $\mathrm{H}-2 \mathrm{~b}$ mice deficient in beta 2 -microglobulin. J Immunol 151:266-276.

Rodriguez M, Pavelko KD, McKinney CW, Leibowitz JL (1994) Recombinant human IL-6 suppresses demyelination in a viral model of multiple sclerosis. J Immunol 153:3811-3821.
Rodriguez M, Roos RP, McGavern D, Zoecklein L, Pavelko K, Sang H, Lin X (2000) The CD4-mediated immune response is critical in determining the outcome of infection using Theiler's viruses with VP1 capsid protein point mutations. Virology 275:9-19.

Roldan E, Brieva JA (1991) Terminal differentiation of human bone marrow cells capable of spontaneous and high-rate immunoglobulin secretion: role of bone marrow stromal cells and interleukin 6. Eur J Immunol 21:2671-2677.

Roldan E, Rodriguez C, Navas G, Parra C, Brieva JA (1992) Cytokine network regulating terminal maturation of human bone marrow $\mathrm{B}$ cells capable of spontaneous and high rate Ig secretion in vitro. J Immunol 149:2367-2371.

Romano M, Sironi M, Toniatti C, Polentarutti N, Fruscella P, Ghezzi P, Faggioni R, Luini W, van Hinsbergh V, Sozzani S, Bussolino F, Poli V, Ciliberto G, Mantovani A (1997) Role of IL-6 and its soluble receptor in induction of chemokines and leukocyte recruitment. Immunity 6:315-325.

Rubio N, De Felipe C, Torres C (1990) Theiler's murine encephalomyelitis virus-binding activity on neural and non-neural cell lines and tissues. J Gen Virol 71:2867-2872.

Sarawar SR, Brooks JW, Cardin RD, Mehrpooya M, Doherty PC (1998) Pathogenesis of murine gammaherpesvirus-68 infection in interleukin-6deficient mice. Virology 249:359-366.

Schafer KH, Mestres P, Marz P, Rose-John S (1999) The IL-6/sIL-6R fusion protein hyper-IL-6 promotes neurite outgrowth and neuron survival in cultured enteric neurons. J Interferon Cytokine Res 19:527-532.

Sidman RL, Angevine JB, Pierce ET (1971) Atlas of the mouse brain and spinal cord. Cambridge, MA: Harvard UP.

Strelau J, Sullivan A, Bottner M, Lingor P, Falkenstein E, Suter-Crazzolara C, Galter D, Jaszai J, Krieglstein K, Unsicker K (2000) Growth/differentiation factor-15/macrophage inhibitory cytokine-1 is a novel trophic factor for midbrain dopaminergic neurons in vivo. J Neurosci 20:8597-8603.

Strestik BD, Olbrich AR, Hasenkrug KJ, Dittmer U (2001) The role of IL-5, IL-6 and IL-10 in primary and vaccine-primed immune responses to infection with Friend retrovirus (Murine leukemia virus). J Gen Virol 82:1349-1354.

Sun N, Grzybicki D, Castro RF, Murphy S, Perlman S (1995) Activation of astrocytes in the spinal cord of mice chronically infected with a neurotropic coronavirus. Virology 213:482-493.

Tosato G, Seamon KB, Goldman ND, Sehgal PB, May LT, Washington GC, Jones KD, Pike SE (1988) Monocyte-derived human B-cell growth factor identified as interferon-beta 2 (BSF-2, IL-6). Science 239:502-504.

Wang J, Homer RJ, Chen Q, Elias JA (2000) Endogenous and exogenous IL-6 inhibit aeroallergen-induced Th2 inflammation. J Immunol 165:4051-4061.

Zhong J, Dietzel ID, Wahle P, Kopf M, Heumann R (1999) Sensory impairments and delayed regeneration of sensory axons in interleukin-6deficient mice. J Neurosci 19:4305-4313. 